\title{
Annual cycle of organic matter partitioning and its availability to bacteria across the Santa Barbara Channel continental shelf
}

\author{
Elisa R. Halewood ${ }^{1,2}$, Craig A. Carlson ${ }^{1,2, *}$, Mark A. Brzezinski ${ }^{1,2}$, Daniel C. Reed ${ }^{1}$, \\ Jo Goodman²
}

${ }^{1}$ Marine Science Institute and ${ }^{2}$ Ecology, Evolution, and Marine Biology, University of California, Santa Barbara, California 93106, USA

\begin{abstract}
Seasonal trends in organic matter (OM) partitioning (between the dissolved and particulate phases), dissolved inorganic nitrogen (DIN) distributions, and bacterioplankton dynamics were examined across a $3 \mathrm{~km}$ stretch of the Santa Barbara Channel continental shelf from January 2008 to April 2009. OM partitioning was assessed as the percentage of ${ }^{14} \mathrm{C}$-primary production (PP) released as ${ }^{14} \mathrm{C}$-labeled dissolved organic carbon (DOC), i.e. percent extracellular release (PER), and as the ratio of DOC and particulate organic carbon (POC) concentrations. Spring upwelling raised surface DIN concentrations, stimulating phytoplankton blooms and OM accumulation. During upwelling, PER accounted for 10 to $30 \%$, with 60\% of OM accumulating as POC versus $\sim 40 \%$ as DOC. After stratification and macronutrient depletion, PER increased to between 35 and $45 \%$, and the proportion of seasonally produced DOC to total accumulated organic carbon increased to $>50 \%$. Experiments revealed a seasonal maximum in DOC bioavailability to heterotrophic bacterioplankton during upwelling: 9 to $18 \%$ of DOC was consumed in $<1$ wk at bacterial growth efficiencies (BGE) of 5 to $12 \%$. Throughout the stratified period, $\leq 5 \%$ of DOC was consumed in $<1 \mathrm{wk}$, and the BGE increased to between 12 and $52 \%$. Bacterial carbon demand (BCD)

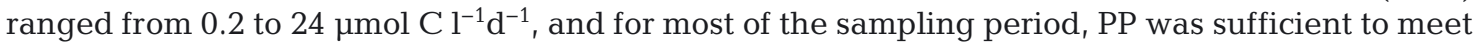
BCD. However, at times, BCD exceeded phytoplankton PP, indicating that sources of DOC other than daily PP were used to support BCD. Similar to other coastal systems, OM is partitioned mainly into the particulate phase under nutrient-replete conditions and into the dissolved phase following stratification and the onset of oligotrophic conditions. We discuss how the partitioning of $\mathrm{OM}$ has consequences for bacterial metabolism and carbon cycling of this coastal system.
\end{abstract}

KEY WORDS: Santa Barbara Channel · Dissolved organic carbon · Bacterial growth efficiency · Bacterial production $\cdot$ Bioavailability $\cdot$ Bacterial carbon demand

Resale or republication not permitted without written consent of the publisher

\section{INTRODUCTION}

In coastal ocean waters, free-living bacterioplankton compose 10 to $30 \%$ of the living carbon biomass (Holligan et al. 1984) and dominate the surface area of living organisms in all marine systems (Pomeroy et al. 2007). Combined with their high phylogenetic (Rappé \& Giovannoni 2003, Giovannoni \& Stingl
2005) and functional (DeLong et al. 2006) diversity, these properties make bacterioplankton major agents in driving marine biogeochemistry. The oxidation of marine dissolved organic matter (DOM) is predominantly governed by heterotrophic bacterioplankton processes (Azam et al. 1983). The efficiency with which bacterioplankton utilize DOM determines whether DOM is repackaged as particles (bac- 
terioplankton cells) and passed to higher trophic levels as a trophic link (Azam et al. 1983) or remineralized to its dissolved inorganic constituents, therefore acting as a trophic sink (Ducklow et al. 1986). The partitioning of the organic matter (OM) generated by autotrophs between the dissolved and particulate phase is thus a key factor governing the fraction of OM processed by heterotrophic bacteria and their contribution to trophodynamics and biogeochemical cycling within any marine ecosystem.

Only a few studies have investigated how the partitioning of OM between dissolved and particulate phase changes seasonally in natural marine systems. Time-series studies in the oligotrophic open sea show that the majority of seasonal OM accumulates in the dissolved phase (Copin-Montegut \& Avril 1993, Carlson et al. 1998). Research in nutrient-replete seas such as the Ross Sea, Antarctica, has demonstrated that $>80 \%$ of OM is partitioned as particulate organic matter (POM) during seasonal phytoplankton blooms (Carlson et al. 1998). In a synthesis of coastal phytoplankton blooms, Williams (1995) suggested that as phytoplankton blooms progress from nutrient-replete to nutrient-depleted conditions, carbon overproduction takes place, leading to the accumulation of carbon-rich DOM. In coastal upwelling systems, similar trends have been observed in which a high percentage of accumulated OM is partitioned into the particulate phase during exponential bloom conditions (Doval et al. 1997, Wetz \& Wheeler 2003), with evidence of greater DOM partitioning during later phase of the bloom (Hill \& Wheeler 2002). Sintes et al. (2010) assessed the seasonal variability of DOM and bacterioplankton dynamics in the coastal North Sea and observed a seasonal transition in the source of organic carbon that supported bacterial carbon demand (BCD). They demonstrated a pronounced seasonal pattern in DOM and found that extracellular release (ER) from primary production (PP) could account for BCD in spring and summer but that in winter periods the accumulated DOM was also required to partially support $\mathrm{BCD}$. Little is known about how DOM bioavailability to heterotrophic bacterioplankton changes as a system transitions from nutrient-replete to nutrient-deplete conditions.

Extracellular release of PP is often quantified by tracing the conversion of $\mathrm{H}^{14} \mathrm{CO}_{3}$ to ${ }^{14} \mathrm{C}$-labeled dissolved organic carbon (DOC) (Fogg 1983). Comparing the ER rates to total PP rates, i.e. percent extracellular release (PER), provides an index of short-term OM partitioning (Sharp 1977, Mague et al. 1980, Sintes et al. 2010). PER in phytoplankton cultures grown in exponential phase generally ranges be- tween 2 and $10 \%$ (Nagata 2000). Field studies have revealed PER values as high as 50\% during nutrient limiting conditions (Karl et al. 1998). However, increased PER can be affected by both increased ER or decreased total PP relative to ER. Thus, the variability of PER based on short-term incubations compared to long-term trends in bulk OM partitioning and DOM accumulation requires further evaluation.

In coastal regions with narrow continental shelves, processes on the inner shallow shelf can be both driven by local processes and influenced by exchange with offshore waters that have inherently different histories of OM cycling. The continental shelf in the Santa Barbara Channel (SBC) is extremely narrow, only a few kilometers wide in many areas, facilitating cross-shelf exchange of materials between the inner shelf and waters beyond the shelf break. Of particular interest in the present study is the supply and export of key resources to and from the nearshore rocky reef environment, which is the focal ecosystem of the Santa Barbara Coastal LongTerm Ecological Research (SBC-LTER) program. The nearshore rocky reefs of the SBC are dominated by forests of giant kelp Macrocystis pyrifera, located at the land-ocean margin in temperate regions of both the northern and southern hemispheres and which represent one of the most productive ecosystems in the world (Mann 1973). The extent of connectivity between rocky reefs in the inner continental shelf and deeper offshore waters therefore has important implications for the flux of OM, nutrients, and energy in the larger SBC ecosystem.

In the present study, we report the evolution and persistence of temporal and spatial gradients in biogeochemical parameters and bacterioplankton dynamics across the continental shelf of the mainland coast in the SBC over an annual cycle. We evaluate the partitioning of OM based on short-term PER experiments and compare that to the accumulated bulk pools of POM and DOM. We also assess patterns in the production and bioavailability of DOC via experimental approaches and explore the significance of bacterioplankton carbon demand in the SBC nearshore environment.

\section{MATERIALS AND METHODS}

\section{Study site and water collection}

The SBC is embedded within the California current system and is influenced by the cool nutrient-rich southward-flowing California Current to the north- 
west, the warm oligotrophic Southern California Current flowing pole ward from the south, and the inshore Southern California Counter Current (SCCC) (Hickey 1979, 1992, Lynn \& Simpson 1987). The eastwest orientation of the SBC coastline causes local upwelling within the SBC to be driven by spatially variable winds and sea-level gradients rather than by the prevailing northwesterly winds that drive upwelling further to the north (Harms \& Winant 1998). Wind-driven upwelling occurs for brief periods along the mainland coast during spring (McPhee-Shaw et al. 2007) and entrains nutrients from depth into the surface water, triggering annual spring phytoplankton blooms. Estimates of phytoplankton PP are as high as $0.71 \mathrm{~mol} \mathrm{C} \mathrm{m}^{-2} \mathrm{~d}^{-1}$, among the highest in the Southern California Bight (Brzezinski \& Washburn 2011).

Monthly oceanographic cruises were conducted from January 2008 to April 2009 aboard the RV 'Kelpfish' that occupied a $3 \mathrm{~km}$ transect comprised of 5 stations extending from Mohawk Kelp Forest (Stn $5,34^{\circ} 23^{\prime} \mathrm{N}, 119^{\circ} 43^{\prime} \mathrm{W}$ ) across the shelf to a depth of $67 \mathrm{~m}$ (Stn 1, 34 $22^{\prime} \mathrm{N}, 119^{\circ} 43^{\prime} \mathrm{W}$ ) (Fig. 1). Seawater was collected using a conductivity, temperature, and depth (CTD) rosette profiler equipped with 41 Niskin bottles containing Teflon-coated springs. Station locations, depths sampled, and samples collected are summarized in Table 1. Samples

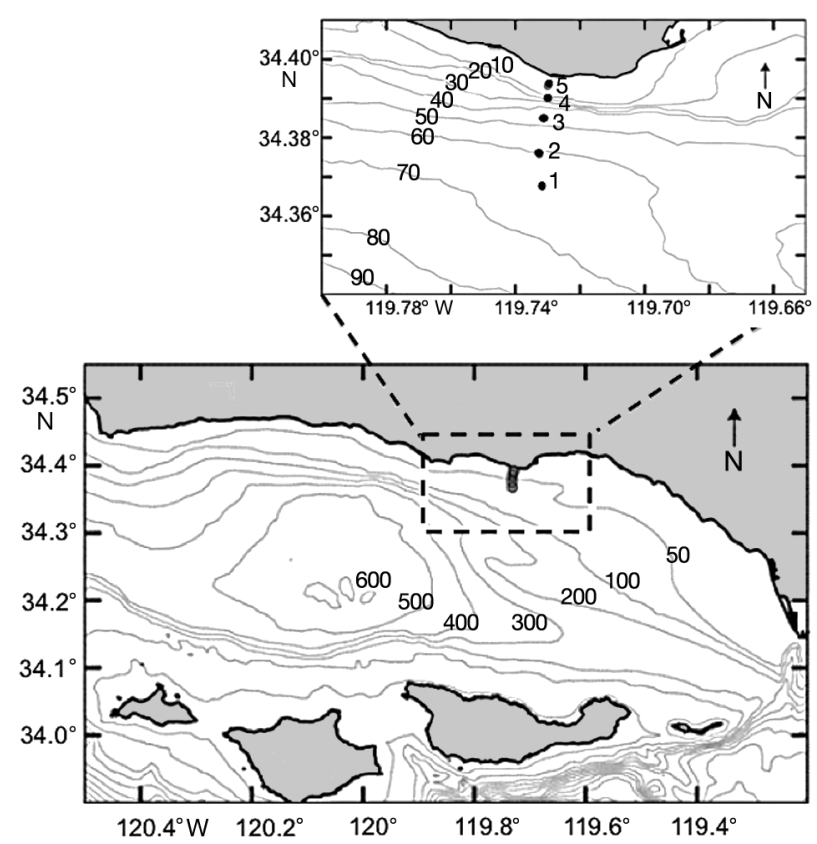

Fig. 1. The Santa Barbara Channel indicating the location of the SBC-LTER Cross Shelf study area (dashed rectangle). Bathymetry contours are in meters. Inset reveals the locations of Stns 1 to 5 (total transect $3 \mathrm{~km}$ ) and bathymetry in meters for DOM, nutrients, and combined phytoplankton PP/PER and bacterial production (BP) were drawn directly from the Niskin bottles into individual acidwashed sample containers. Nutrients and DOM samples were placed on ice, and PP/PER and BP samples were maintained at in situ temperatures for the duration of the cruise ( 3 to $4 \mathrm{~h}$ ). The remaining water volume was then emptied from each Niskin bottle into separate acid-cleaned $4 \mathrm{l}$ high density polyethylene (HDPE) bottles, placed in coolers, and this water was used for all subsequent chemical and biological analyses back in the shore-based laboratory. All field data from the present study are available at http:// sbc.lternet.edu.

\section{Bacterial abundance and biomass}

Bacterioplankton were enumerated using an LSR II flow cytometer (BD Biosciences) equipped with a $488 \mathrm{~nm}$ excitation laser and standard filter set as described previously (Marie et al. 1997, Campbell 2001, Ewart et al. 2008). Aliquots of $1 \mathrm{ml}$ of seawater were fixed with $0.2 \mu \mathrm{m}$ filtered fresh paraformaldehyde (final concentration $0.2 \%$ ). After 1 to $4 \mathrm{~h}$, the samples were placed in long-term storage at $-80^{\circ} \mathrm{C}$ (Vaulot et al. 1989). Prior to analysis, samples were thawed and the cells stained with SYBR Green I (Molecular Probes) at a final concentration of 1:10000 (vol:vol) for at least $30 \mathrm{~min}$ in the dark and analyzed within 60 min of staining (Marie et al. 1997, Campbell 2001). The LSR II analytical performance was evaluated for quality control with $3.0 \mu \mathrm{m}$ Rainbow beads (Spherotech). All field samples collected in 2008 were analyzed using a daily calibration of instrument flow rate conducted by measuring the change in the weight of $1 \mathrm{ml}$ samples of deionized water before and after running for between 5 and 10 min on the LSR II. Data for samples was then acquired in log mode for at least $60 \mathrm{~s}$ or until 20000 events were recorded, with the minimum green fluorescence (channel 200) set as the threshold. Gating analyses of specific populations were performed using FACS Diva software (BD Biosciences). Bacterial abundances (cells $\mathrm{ml}^{-1}$ ) were determined from sample flow rates and number of events recorded (Campbell 2001, Ewart et al. 2008).

A high throughput system (HTS, BD Biosciences) was added to the LSR II in 2009. All 2009 samples were analyzed using this HTS system, which injected a fixed volume of $45 \mu \mathrm{l}$ per sample drawn from a pre-loaded 96 well plate. Comparative tests with and without the HTS showed no significant differences in cell enumeration (data not shown). Bac- 


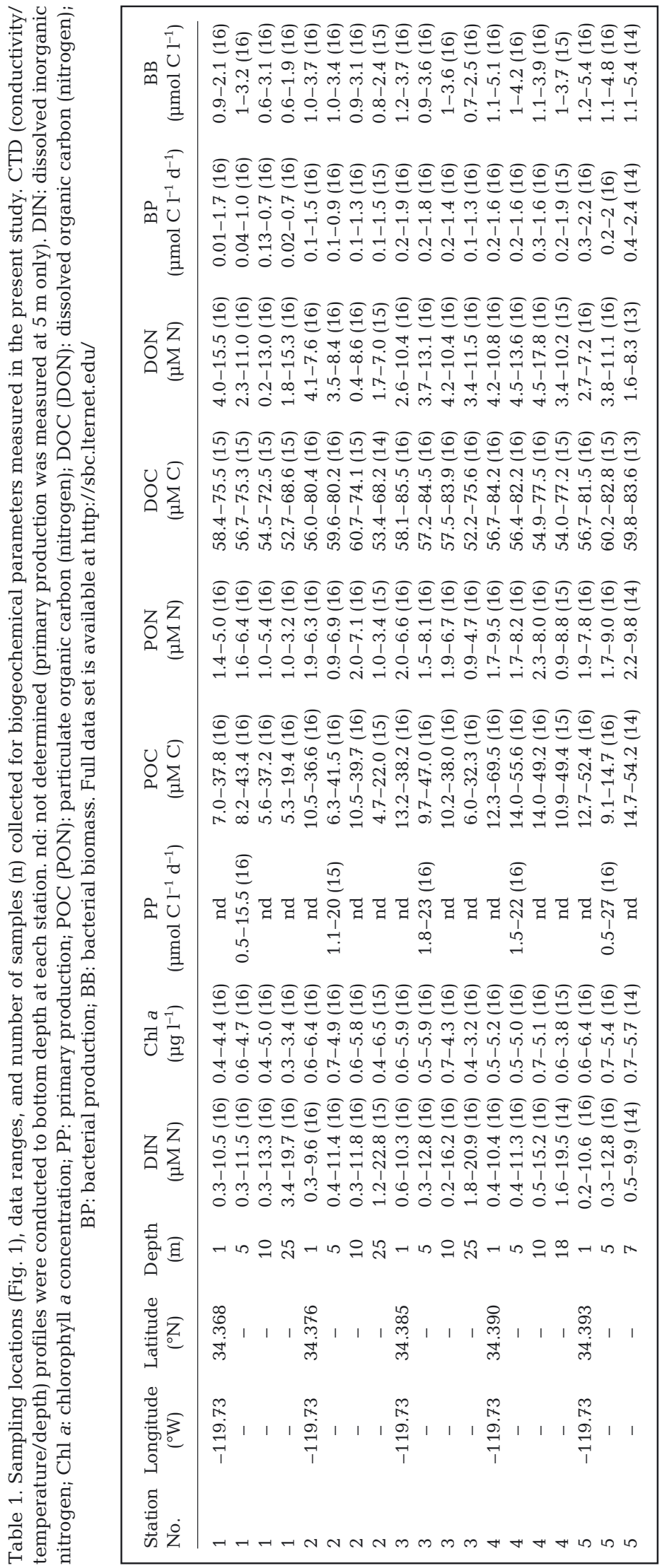

terial biomass (BB) was estimated from cell abundance using a carbon conversion factor of $15 \mathrm{fg} \mathrm{C} \mathrm{Cell}^{-1}$, as has been determined for bacterioplankton in this region (A. Cano unpubl. data) and which is in agreement with conversion factors reported previously (Lee \& Fuhrman 1987).

\section{Bacterial production}

Heterotrophic BP was estimated by 3,4,5${ }^{3} \mathrm{H}$-leucine $\left({ }^{3} \mathrm{H}-\mathrm{leu} ; \mathrm{SA}=115.4 \mathrm{Ci} \mathrm{mmol}{ }^{-1}\right.$; Perkin Elmer) incorporation using the microcentrifuge method (Smith \& Azam 1992), with slight modifications (decanting the supernatant instead of aspirating). All incubations were conducted in the shore-based laboratory. Samples were spiked to a final concentration of $20 \mathrm{nM}{ }^{3} \mathrm{H}$-leu and incubated for 1 to $2 \mathrm{~h}$ in the dark within $2^{\circ} \mathrm{C}$ of in situ temperature. Radioactivity was analyzed by a Beckman Coulter LS6500 Multipurpose scintillation counter corrected with an external standard and quench curve. ${ }^{3} \mathrm{H}$-leu incorporation rates were converted to BP using the conversion factor of $1.5 \mathrm{~kg} \mathrm{C} \mathrm{mol}{ }^{-1}$ leu incorporated (Simon \& Azam 1989). Bacterial specific growth rates $(\mu)$ were then calculated as:

$$
\mu=\mathrm{BP} / \mathrm{BB}
$$

\section{DOM analysis}

Seawater samples for DOC and dissolved organic nitrogen (DON) were passed through a $47 \mathrm{~mm}$ polycarbonate cartridge housing combusted glass fiber filters (GF/F, $0.7 \mu \mathrm{m}$ pore size) and collected into acid-washed 60 ml HDPE bottles. Samples were analyzed via high-temperature combustion for DOC (Carlson et al. 2010) and total dissolved nitrogen (TDN) (Farmer \& Hansell 2007) using a Shimadzu TOC-V. DON was calculated as the difference between TDN and dissolved inorganic nitrogen (DIN) measured as described below. All samples were systematically referenced against low carbon water, deep (2600 m), and surface Sargasso Sea reference water, every 6 to 8 analyses (Hansell \& Carlson 1998, Carlson et al. 2004). Daily reference waters were calibrated with DOM consensus reference waters (Hansell 2005). 


\section{POM analysis}

The particulate matter from $630 \mathrm{ml}$ was collected by vacuum filtration ( $\leq 10 \mathrm{~mm} \mathrm{Hg}$ ) onto pre-combusted $25 \mathrm{~mm}$ GF/F filters $(0.7 \mu \mathrm{m}$ pore size, Whatman; $450^{\circ} \mathrm{C}$ for $5 \mathrm{~h}$ ) for combined particulate organic carbon (POC) and nitrogen (PON) analysis. The filters were then placed into combusted $20 \mathrm{ml}$ glass scintillation vials. These vials were placed with caps off into a covered glass dish in a fume hood, with a $20 \mathrm{ml}$ beaker of concentrated $\mathrm{HCl}$ in the center to fume overnight to remove carbonates. Samples were then placed in a $65^{\circ} \mathrm{C}$ oven until completely dry. They were analyzed on a model CEC 440HA CHN organic elemental analyzer (Control Equipment, now Exeter Analytical).

\section{Phytoplankton primary production and extracellular release}

Phytoplankton PP was measured using water samples collected at $5 \mathrm{~m}$ for all stations, using a modified Joint Global Ocean Flux Study $\mathrm{H}^{14} \mathrm{CO}_{3}$ method (Brzezinski \& Washburn 2011). At these same stations and depths, ER was measured using a modification of the technique and apparatus of Smith et al. (1977) that allowed the filtrate from the ${ }^{14} \mathrm{C}$-PP experiments to be collected. The first $10 \mathrm{ml}$ of filtrate from each PP sample was collected in individual clean $20 \mathrm{ml}$ glass scintillation vials, acidified with $0.5 \mathrm{ml}$ of $0.13 \mathrm{M} \mathrm{HCl}$, and bubbled with room air to remove inorganic ${ }^{14} \mathrm{C}$. Each sample was then divided into two $4 \mathrm{ml}$ aliquots in glass scintillation vials and evaporated to dryness in a vacuum oven at $70^{\circ} \mathrm{C}$. Then, each sample was reconstituted with $4 \mathrm{ml}$ deionized distilled water and $16 \mathrm{ml}$ of Ecolume scintillation cocktail (MP Biomedicals). After allowing a minimum of $2 \mathrm{~h}$ for chemoluminescence to subside, the ${ }^{14} \mathrm{C}$ activity in the DOC pool was quantified by liquid scintillation counting. The ER rate was calculated as:

$$
\mathrm{ER}=\left(\mathrm{DPM}_{\mathrm{F}} / \mathrm{DPM}_{\text {Tot }}\right) \times[\mathrm{DIC}] \times 1.05 \times \mathrm{t}^{-1}
$$

where $\mathrm{DPM}_{\mathrm{F}}$ is the ${ }^{14} \mathrm{C}$ activity (disintegrations per minute) per liter in the filtrate, $\mathrm{DPM}_{\text {Tot }}$ is the total ${ }^{14} \mathrm{C}$ activity per liter in the sample, [DIC] is the concentration of inorganic carbon in seawater $(25 \mathrm{mg}$ $\mathrm{C}^{-1}$ ), 1.05 is a correction factor to account for the preferential uptake of ${ }^{12} \mathrm{C}$ over ${ }^{14} \mathrm{C}$, and $t$ is the duration of the incubation $(\sim 24 \mathrm{~h})$. PER was calculated as the ratio of ER to total PP (i.e. the sum of ER and PP) $\times 100 \%$.

\section{Partitioning of accumulated OM}

Changes in DOC $(\triangle \mathrm{DOC})$ and POC $(\triangle \mathrm{POC})$ relative to the annual minimum in both properties were used to examine temporal and spatial changes in the relative accumulation of particulate and dissolved organic carbon across the shelf. To calculate $\triangle \mathrm{DOC}$ and $\triangle \mathrm{POC}$, profiles of DOC and POC were integrated to 7 to $10 \mathrm{~m}$ and normalized to the depth of integration. The annual minimum for DOC and POC was calculated as the average of the 10 lowest concentrations for each parameter observed within the surface $10 \mathrm{~m}$, i.e. $56.2 \pm 0.9 \mu \mathrm{mol} \mathrm{l}^{-1}$ for DOC observed in spring/ winter of 2008 and 2009 and $8.4 \pm 1.3 \mu \mathrm{mol} \mathrm{l}^{-1}$ for POC observed in winter 2008 and 2009. $\triangle$ DOC and $\triangle$ POC values were then calculated by subtracting this average annual minimum for DOC and POC from the $10 \mathrm{~m}$ integrated depth normalized values at each station through time. The percentage of accumulated OM present as DOC (\%DOC $\left.\mathrm{TOC}_{\mathrm{TO}}\right)$ was calculated as:

$$
\% \mathrm{DOC}_{\mathrm{TOC}}=[\Delta \mathrm{DOC} /(\Delta \mathrm{DOC}+\Delta \mathrm{POC})] \times 100
$$

\section{Nutrient analysis}

Samples were passed through $47 \mathrm{~mm}$ diameter Nuclepore filters $(0.6 \mu \mathrm{m}$ pore size) housed in an inline filter holder that had been flushed with sample and collected in a $20 \mathrm{ml}$ HDPE scintillation vial. The samples were stored at $-20^{\circ} \mathrm{C}$ until analysis of dissolved inorganic nutrients (nitrite, nitrate plus nitrite, ortho-phosphate, silicate, and ammonium). DIN represents the sum of $\mathrm{NO}_{2}{ }^{-}+\mathrm{NO}_{3}{ }^{-}+\mathrm{NH}_{4}{ }^{+}$. Analysis was performed using flow injection techniques on a QuickChem 8000 (Lachat Instruments Division, Zellweger Analytics). Detection limits for $\mathrm{NO}_{2}{ }^{-}$, $\mathrm{NO}_{2}{ }^{-}+\mathrm{NO}_{3}{ }^{-}, \mathrm{PO}_{4}{ }^{3-}, \mathrm{Si}(\mathrm{OH})_{4}$, and $\mathrm{NH}_{4}{ }^{+}$were $0.1,0.2$, $0.1,1.0$, and $0.1 \mu \mathrm{M}$, respectively.

\section{Remineralization experiments}

Remineralization bioassay experiments were used to assess bioavailability of the DOC pool to heterotrophic bacterioplankton over short ( $\leq 1 \mathrm{wk}$ ) and long (1 to 2 mo) time scales (Carlson et al. 2002). Seawater was drawn from $\sim 1$ to $5 \mathrm{~m}$ depth into $\mathrm{HCl}$-cleaned 201 carboys using a peristaltic pump and silicone tubing at Stns 1 and 5 during each cruise, providing samples from the inner and outer shelf. Due to the labor-intensive nature of this work, the remineralization bioassay experiments were restricted to water 
drawn from Stns 1 and 5 within the surface $5 \mathrm{~m}$. The results are taken to be representative of the DOM and bacterial activity within the surface mixed layer, i.e. top $\sim 5 \mathrm{~m}$. Due to logistical constraints, the water for media and inocula was collected from Stns 1 and 5 the day after the cross-shelf cruise in May and August 2008. As a result, the initial experimental DOC values for the experiments differ slightly from the time-series in situ data.

A key aspect of the experimental design for the bioassays was that natural bacterial assemblages from Stns 1 and 5 collected during each cruise were used as inocula to more accurately reflect the capacity of the extant bacterioplankton to take up and process the respective nearshore and offshore DOM. To remove large POM and attached microbial assemblages from the bacterial inoculum, whole seawater was gravity filtered from the 201 carboy through an in-line $142 \mathrm{~mm}$ Supor filter (3.0 $\mu \mathrm{m}$ pore size) housed in a polycarbonate GeoTech filter holder (Geotech Environmental Equipment) within $\sim 4 \mathrm{~h}$ of collection. The filters were flushed of DOM by passing at least $2 \mathrm{l}$ of ultraviolet radiation [UV] oxidized Nanopure ${ }^{\circledR}$ water (Barnstead Thermoline) and 0.51 of sample water through the filter before sample collection to minimize contamination by DOC leached from the polysulfone membranes (Carlson et al. 2004). The $3.0 \mu \mathrm{m}$ filtrate and associated bacteria were retained in an acid-cleaned polycarbonate carboy. Bacteria were removed from a portion of the filtrate by gravity filtration through a pre-flushed $142 \mathrm{~mm}$ Supor filter $(0.2 \mu \mathrm{m})$. Seawater dilution cultures consisted of 81 polycarbonate carboys containing $6.4 \mathrm{l}$ of the $0.2 \mu \mathrm{m}$ filtrate inoculated with $1.6 \mathrm{l}$ of $3.0 \mu \mathrm{m}$ filtrate containing bacterioplankton (i.e. $80 \%$ filtrate and $20 \%$ inoculum). Flagellate grazers were not enumerated in the present study; however, these dilution cultures are designed to dilute grazing pressure and allow bacterioplankton to respond to bottom up controls.

The carboys were placed in an environmental chamber and incubated in the dark at in situ temperatures (to within $2^{\circ} \mathrm{C}$ of surface water temperature at the time of collection). Samples for bacterial abundance and DOC concentration were collected at regular intervals (typically every 12 to $24 \mathrm{~h}$ ) for $1 \mathrm{wk}$. Additional DOC samples were collected at regular intervals for up to 2 mo after the beginning of the experiments. Although remineralization experiments were attempted on a monthly basis, in some cases, the samples were inadvertently exposed to surface or airborne DOC contaminants at the time of experi- mental setup or sampling, and these cultures were eliminated from further analyses. Successful experiments were obtained from cruises in January, February, May, June, August, September, November, and December of 2008.

The percent bio-available DOC (\%BDOC) over the short term $\left(\% \mathrm{BDOC}_{1 \mathrm{wk}}\right)$ was calculated as:

$$
\begin{aligned}
\% \mathrm{BDOC}_{1 \mathrm{wk}}= & {\left[\left(\mathrm{DOC}_{\text {initial }}-\mathrm{DOC}_{1 \mathrm{wk}}\right) /\right.} \\
& \left.\mathrm{DOC}_{\text {initial }}\right] \times 100
\end{aligned}
$$

where $\mathrm{DOC}_{1 \mathrm{wk}}$ is the DOC removed over the shortterm ( $\leq 1 \mathrm{wk}_{\text {; }}$ see Table 5). For comparative purposes, the long-term DOC removal was standardized to $26 \mathrm{~d}$ $\left(\mathrm{DOC}_{\mathrm{Std} 26}\right)$ (i.e. the shortest duration of the extended incubations). The $\mathrm{DOC}_{\mathrm{Std} 26}$ value was interpolated from a logarithmic curve fit of the T0, $<1 \mathrm{wk}$, and long-term incubation values (see Table 5 for incubation times, DOC concentration, and $r^{2}$ value of the curve fit) for experiments that were incubated $>26 \mathrm{~d}$. We calculated \%BDOC ${ }_{\text {Std26 }}$ (i.e. the \%BDOC removed between 1 wk and $26 \mathrm{~d}$ normalized to initial DOC concentration) as follows:

$$
\begin{aligned}
\% \mathrm{BDOC}_{\mathrm{Std} 26}= & {\left[\left(\mathrm{DOC}_{1 \mathrm{wk}}-\mathrm{DOC}_{\mathrm{Std} 26}\right) /\right.} \\
& \left.\mathrm{DOC}_{\text {initial }}\right] \times 100
\end{aligned}
$$

BGE was calculated as the maximal change in bacterial carbon and corresponding DOC removal within the first week of the incubations:

$$
\mathrm{BGE}=\left(\mathrm{BB}_{1 \mathrm{wk}}-\mathrm{BB}_{\text {initial }}\right) /\left(\mathrm{DOC}_{\text {initial }}-\mathrm{DOC}_{1 \mathrm{wk}}\right)
$$

BCD was estimated from in situ BP (upper $5 \mathrm{~m}$ ) and BGE data as follows:

$$
\mathrm{BCD}=\mathrm{BP} / \mathrm{BGE}
$$

\section{Physical state criteria}

To examine patterns in the context of seasonal changes in the physical environment, periods of upwelling and of weak and strong stratification were identified using the vertical temperature distribution. Stn 5 had a much shallower bottom depth (maximum of $10 \mathrm{~m}$ ) compared to Stns 1 to 4 , and water column temperature was fairly uniform. The temperature gradient at Stn 5 was not representative of the transect, and this station was excluded from the determination of physical state.

Upwelling months were designated as those in which the $11^{\circ} \mathrm{C}$ isotherm, indicative of nutrient-rich deep water of the California Current System (Collins et al. 2000), shoaled from a depth of below $60 \mathrm{~m}$ into the upper $25 \mathrm{~m}$ of the water column. 
Remaining months were classified as either weakly or strongly stratified based on the strength of the temperature gradient over the water column at Stns 1 to 4 . The temperature gradient was calculated as the change in temperature $\left({ }^{\circ} \mathrm{C}\right)$ per meter, averaged over the top $20 \mathrm{~m}$ of the water column. A gradient of $>0.12^{\circ} \mathrm{C} \mathrm{m}^{-1}$ was classified as strongly stratified, while a gradient of $<0.12^{\circ} \mathrm{C} \mathrm{m}^{-1}$ was classified as weakly stratified.

\section{Data analysis}

Contour plots were created using the software program Ocean Data View v4.1.3 (Schlitzer 2009). The effects of physical state and cross shelf distance (as determined by degree latitude on north-south transect) on selected biogeochemical variables (integrated and depth normalized) were evaluated by analysis of covariance (ANCOVA) in which the physical state was considered a fixed factor and latitude was the covariate. All statistical analyses were performed with JMP 9.0 (SAS Institute).
Fig. 3 illustrates profile data that have been integrated (to 7 to $10 \mathrm{~m}$ ), depth normalized, and presented as a surface map where the distributions of parameters across the transect (y-axis) are displayed through time ( $x$-axis). The time-series began with weak stratification in the winter of 2008 and upper water column DIN at moderate concentrations (between 1 and $7 \mu \mathrm{M}$ ) (Fig. 3a), with relatively low concentrations of DOC (i.e. $<65 \mu \mathrm{M} \mathrm{C}$ ) (Fig. 3b) and POM $(<20 \mu \mathrm{M}$ POC and $<3 \mu \mathrm{M}$ PON) (Fig. 3c). Surprisingly, DON concentrations at this time were elevated (i.e. as high as $10 \mu \mathrm{M} N$ ) (Fig. 3b contours).

Upwelling across the shelf was apparent in March through May 2008, when the spatial distribution of macronutrients largely paralleled that of temperature (compare Figs. 2a \& 3a), with high DIN concentrations (2 to $10 \mu \mathrm{M}$ ) across the shelf (Fig. 3a). During the latter half of the 2008 upwelling period, DOC concentrations increased to $\sim 70 \mu \mathrm{M} \mathrm{C}$, with POC and PON increasing to $\sim 25 \mu \mathrm{M} \mathrm{C}$ and 4 to $5 \mu \mathrm{M} \mathrm{N}$, respectively. DON concentrations fell to $\sim 5$ to $6 \mu \mathrm{M} \mathrm{N}$ driving an increase in the $\mathrm{C}: \mathrm{N}$ ratio of $\mathrm{DOM}$ to between 12 and 16 (Fig. 4a).

\section{RESULTS}

\section{Physical dynamics and cross-shelf biogeochemical gradients}

Cross-shelf gradients in temperature were very weak at all times of the year, but there was a strong seasonal trend in temperature, with the coolest surface temperatures present during spring upwelling followed by a gradual warming with the highest temperatures observed in August and September 2008 (Fig. 2). Waters then cooled to 13 to $14^{\circ} \mathrm{C}$ during winter. Upwelling of cold waters occurred again in April 2009. The temporal distributions of the 3 physical states upwelling, strongly stratified, and weakly stratified - are given in Fig. 2. Upwelling was observed in March, April, and May 2008 and in April 2009, with strongly stratified conditions observed from June through September 2008. Weakly stratified conditions were observed between January and February 2008 and again from October 2008 through March 2009.

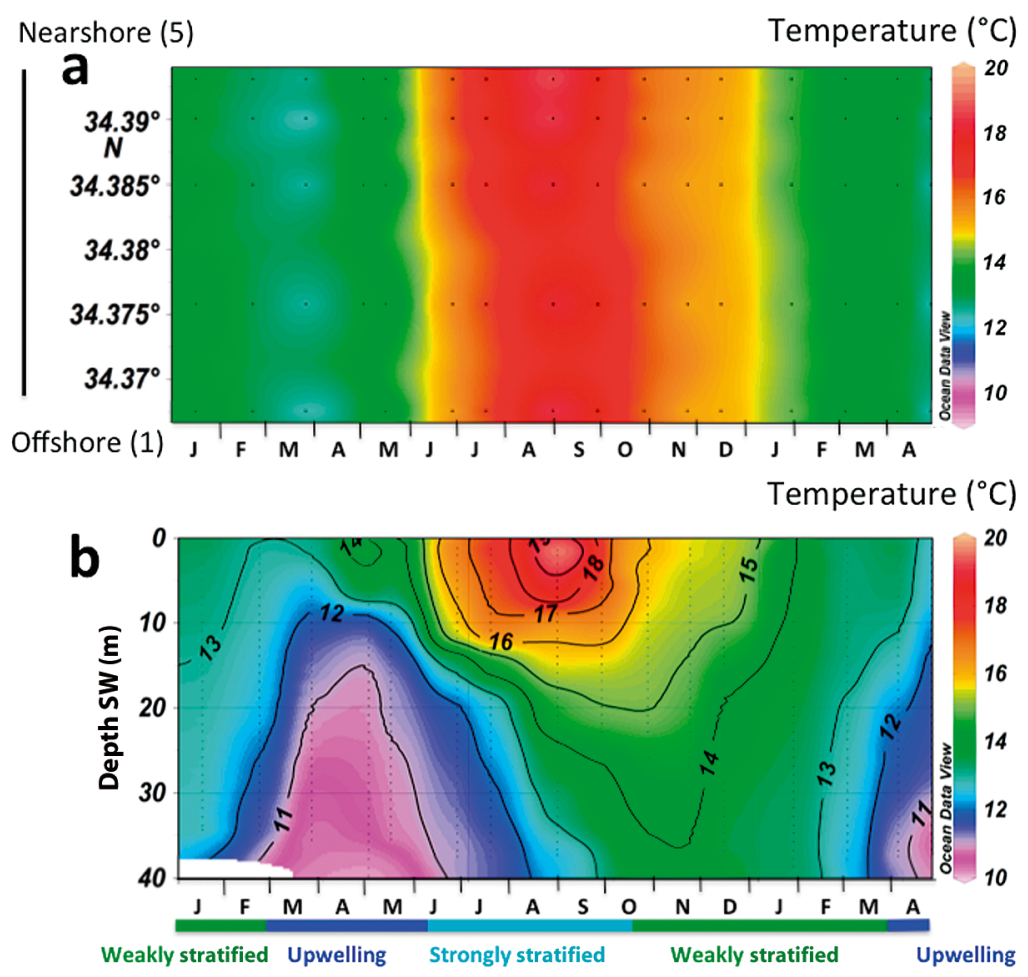

Fig. 2. (a) Surface map of average (0 to $10 \mathrm{~m}$ ) temperature over time and (b) temperature profiles over the top $40 \mathrm{~m}$ of the water column at Stn 3 (midtransect) from January 2008 to April 2009, showing periods of weak stratification, upwelling, and strong stratification. Corresponding physical states were assigned to each month as indicated by bottom color key 


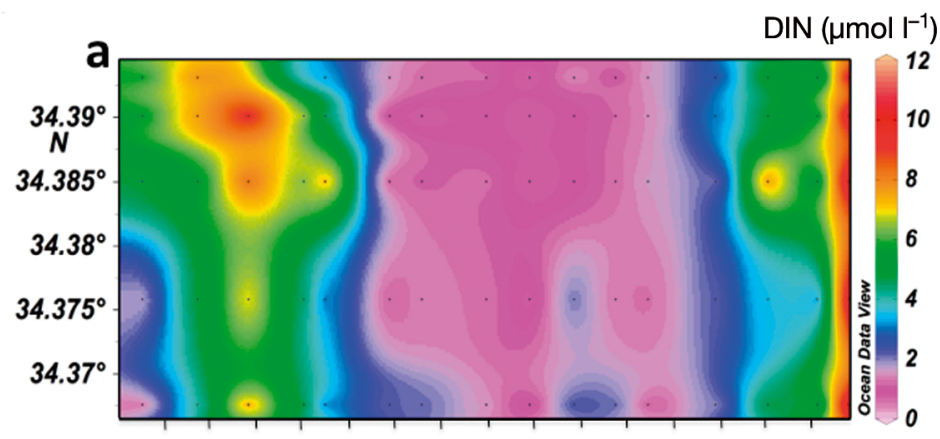

Nearshore (5) DON ( $\left.\mu \mathrm{mol} \mathrm{I}^{-1}\right)$ - Contours

$\mathrm{DOC}\left(\mu \mathrm{mol}{ }^{-1}\right)$
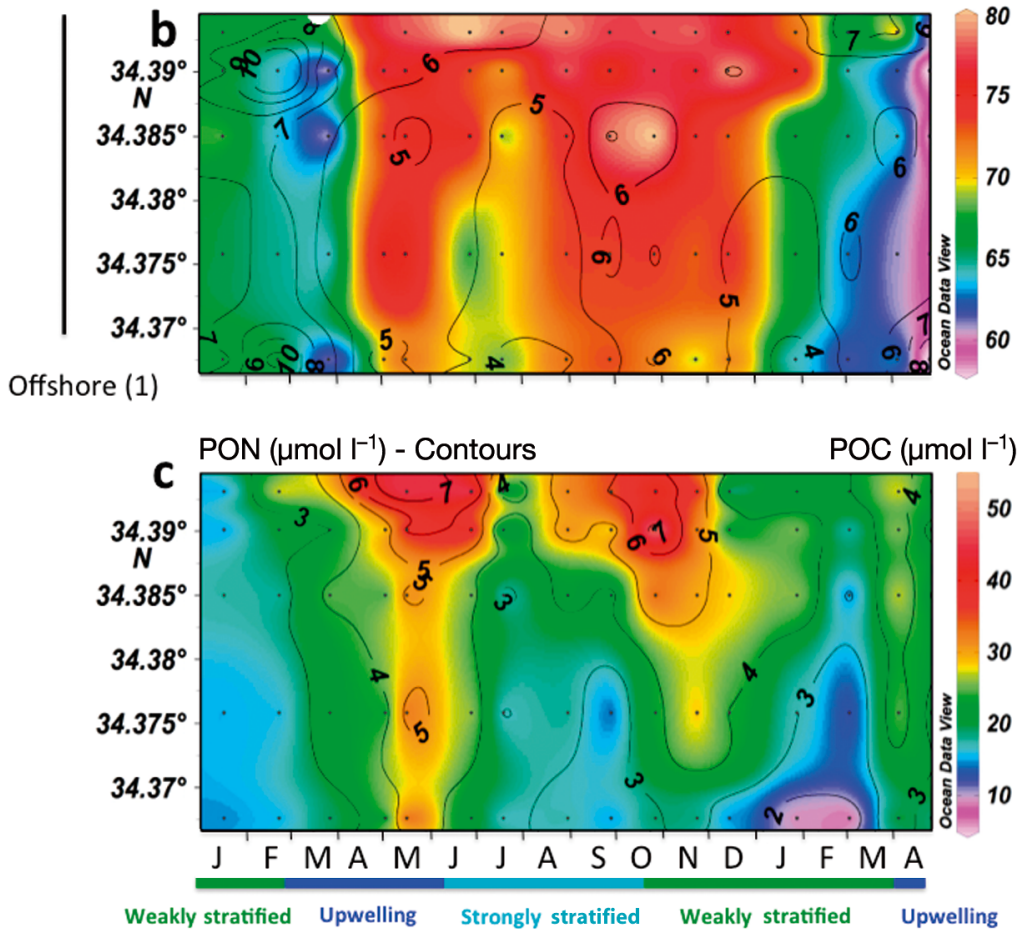

Fig. 3. Surface map of integrated (within the surface $10 \mathrm{~m}$ ) and depth normalized measures of (a) dissolved inorganic nitrogen (DIN), (b) dissolved organic carbon (DOC; color shading) and nitrogen (DON; contour lines), and (c) particulate organic carbon ( $\mathrm{POC}_{i}$ color contours) and nitrogen (PON; contour lines) across 5 stations within the inner shelf region of the Santa Barbara Channel from January 2008 to April 2009

As the water column became strongly stratified in June 2008, DIN concentrations became depleted (0 to $2 \mu \mathrm{M})$, and pronounced cross-shelf gradients in DOC concentrations developed, which subsequently weakened (Fig. 3). The onset of weak stratification in October 2008 was accompanied by surface cooling (Fig. 2a). DOC concentrations remained high across the shelf through December 2008. By January 2009, temperatures declined (Fig. 2a), DIN concentrations increased (Fig. 3a), and DOC concentrations decreased (Fig. 3b). In contrast to the trend in DOC, DON concentrations remained elevated across the shelf under weak stratification (Fig. 3b), lowering the C:N ratio within DOM (Fig. 4a). Upwelling was again apparent during the final sampling date in April 2009, as evidenced by a sharp increase in DIN concentrations and low DOC concentrations across the transect. DON concentrations remained at 6 to $7 \mu \mathrm{M}$, resulting in $\mathrm{C}: \mathrm{N}$ ratios in DOM of $<12$ (Fig. 4a)

The effects of physical state and cross shelf gradients were evaluated by ANCOVA for the integrated and depth normalized variables of DIN, DOC, POC, PON, DON, BP, BB, $\mu$, DOM C:N ratio, and $\% \mathrm{DOC}_{\mathrm{TOC}}$. In all cases, the interaction term in the ANCOVA analyses was not significant (i.e. $p>0.3$ ), indicating that if a cross shelf gradient was observed, significant differences could not be resolved between physical states. The statistical results from these analyses are presented as regression plots (Fig. 5), with all data presented in an effect test table for each variable (Table 2).

The relationship between DIN and DOC concentrations was examined to evaluate the role of phytoplankton nutrient stress on OM partitioning. There was a strong negative correlation between depth normalized integrated concentrations of DIN and DOC in the overall dataset (Table 3). This relationship was related to changes in DIN with physical state (Fig. 5a, Table 2), with DIN concentrations differing significantly among all physical states, decreasing significantly from upwelling $($ mean $=7.4 \mu \mathrm{M})$ to weakly stratified to strongly stratified physical states (mean $=3.1$ and $1.0 \mu \mathrm{M}$, respectively) (Tukey test, $\alpha=0.05$ ) (Fig. 5a). DOC concentrations also varied with physical state (Fig. 5b, Table 2), but in contrast to DIN, DOC concentrations were significantly greater during strongly stratified periods (mean $=73.8 \mu \mathrm{M}) \mathrm{com}$ pared to weakly stratified $($ mean $=69.3 \mu \mathrm{M})$ and upwelling conditions $($ mean $=66.9 \mu \mathrm{M})$, which were not significantly different from each other (Tukey test, $\alpha=0.05$ ) (Fig. 5a). Significant cross-shelf gradients were also observed for DOC; however, we were not able to resolve a cross-shelf gradient in DIN concentrations (Figs. 3a \& 5a, Table 2). 


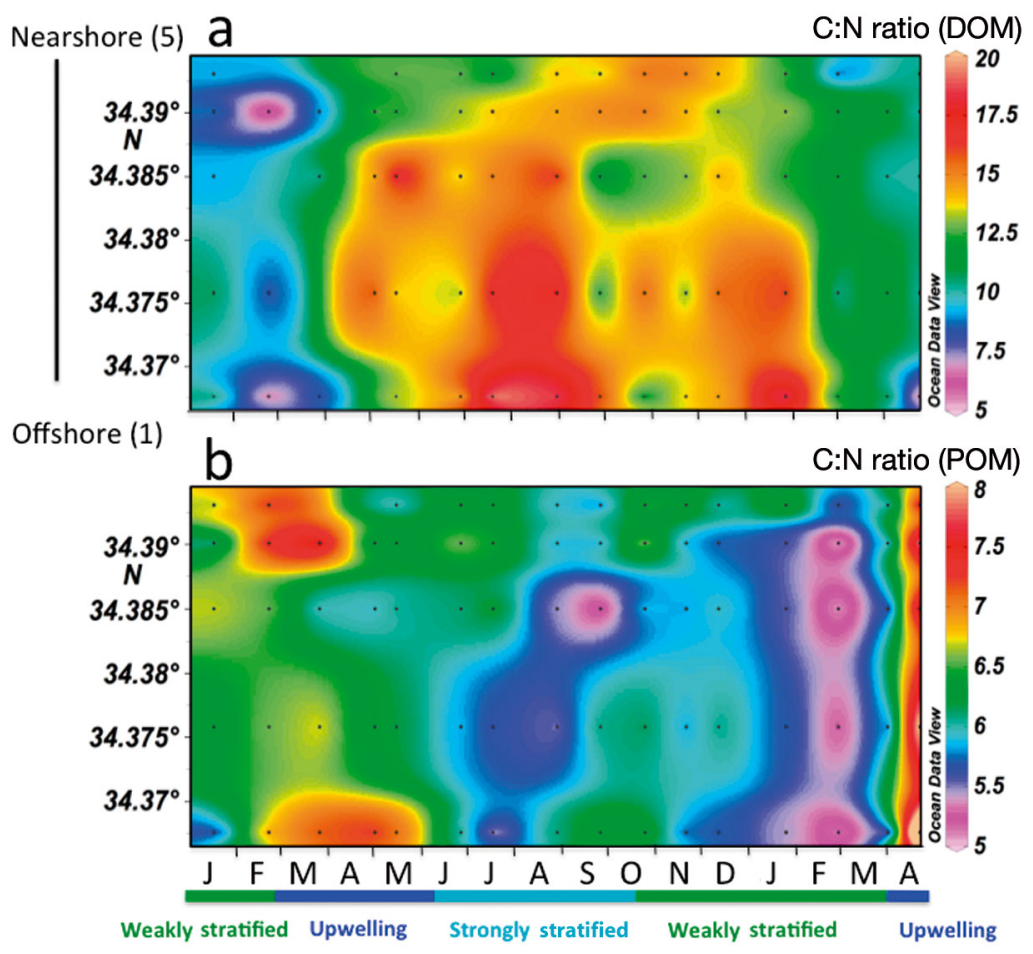

Fig. 4. Surface map of the C:N ratio of integrated stocks of (a) dissolved organic matter (DOM) and (b) particulate organic matter (POM) across the 5 stations within the inner shelf region of the Santa Barbara Channel from January 2008 to April 2009

There was no significant relationship between POC or PON concentration and physical state as periods of elevated POC and PON were observed during upwelling and also during strongly and weakly stratified conditions (Table 2). PON and POC concentrations were positively correlated with PP (Table 3), suggesting a close tie between their accumulation and periods of enhanced PP. There were statistically significant cross-shelf gradients in POC and PON (Figs. 3c \& 5c,d, Table 2), again, with the highest concentrations observed nearshore.

The average C:N ratio for integrated and depth normalized POM varied little $(6.3 \pm 0.97 \mathrm{SD})$ through time (Fig. 4b); however, the C:N ratio of DOM was more variable and became significantly carbon-rich during strongly stratified periods (mean C:N value $=14.6$; Tukey test, $\alpha=0.05$ ) (Fig. 4a, Table 2), when inorganic nutrients were depleted compared to the weakly stratified (mean $\mathrm{C}: \mathrm{N}=12.2$ ) or upwelling periods (mean $\mathrm{C}: \mathrm{N}=11.6)$. No cross-shelf gradient was observed in the C:N ratio of DOM (Fig. 5f, Table 2). Although no significant cross-shelf gradients or variability among physical states could be resolved for DON (Fig. 5e, Table 2), correlation analyses showed that variability in DON concentrations were most strongly correlated (negatively) to the C:N ratio of DOM, indicating that DON variability was most important in driving $\mathrm{C}: \mathrm{N}$ ratios of DOM (Fig. 4a, Table 3).

Table 2. Effect test from ANCOVA where the independent variables are physical state (categorical) and latitude (continuous). The ANCOVA interaction term was insignificant $(p>0.3)$ for all variables. The data can be used to further evaluate the cross shelf regression plots presented in Fig. 5. The p-values in bold are significant

\begin{tabular}{|c|c|c|c|c|c|c|c|c|c|}
\hline Variable & Source & $\mathrm{df}$ & $F$ & $\mathrm{p}$ & Variable & Source & $\mathrm{df}$ & $F$ & $\mathrm{p}$ \\
\hline DIN & $\begin{array}{l}\text { Physical state } \\
\text { Latitude } \\
\text { Error }\end{array}$ & $\begin{array}{c}2 \\
1 \\
74\end{array}$ & $\begin{array}{c}1.56 \\
43.48\end{array}$ & $\begin{array}{c}<\mathbf{0 . 0 0 0 1} \\
0.22\end{array}$ & C:N DOM & $\begin{array}{c}\text { Physical state } \\
\text { Latitude } \\
\text { Error }\end{array}$ & $\begin{array}{c}2 \\
1 \\
69\end{array}$ & $\begin{array}{l}5.29 \\
1.13\end{array}$ & $\begin{array}{c}\mathbf{0 . 0 0 7 3} \\
0.29\end{array}$ \\
\hline DOC & $\begin{array}{c}\text { Physical state } \\
\text { Latitude } \\
\text { Error }\end{array}$ & $\begin{array}{c}2 \\
1 \\
73\end{array}$ & $\begin{array}{l}6.07 \\
6.97\end{array}$ & $\begin{array}{l}0.0036 \\
0.0101\end{array}$ & $\% \mathrm{DOC}_{\mathrm{TOC}}$ & $\begin{array}{c}\text { Physical state } \\
\text { Latitude } \\
\text { Error }\end{array}$ & $\begin{array}{c}2 \\
1 \\
73\end{array}$ & $\begin{array}{c}14.96 \\
5.57\end{array}$ & $\begin{array}{c}<0.0001 \\
0.0209\end{array}$ \\
\hline POC & $\begin{array}{l}\text { Physical state } \\
\text { Latitude } \\
\text { Error }\end{array}$ & $\begin{array}{c}2 \\
1 \\
74\end{array}$ & $\begin{array}{l}1.345 \\
15.59\end{array}$ & $\begin{array}{l}0.2668 \\
\mathbf{0 . 0 0 0 2}\end{array}$ & $\mathrm{BP}$ & $\begin{array}{c}\text { Physical state } \\
\text { Latitude } \\
\text { Error }\end{array}$ & $\begin{array}{c}2 \\
1 \\
74\end{array}$ & $\begin{array}{c}2.11 \\
24.46\end{array}$ & $\begin{array}{c}0.13 \\
<\mathbf{0 . 0 0 0 1}\end{array}$ \\
\hline PON & $\begin{array}{l}\text { Physical state } \\
\text { Latitude } \\
\text { Error }\end{array}$ & $\begin{array}{c}2 \\
1 \\
74\end{array}$ & $\begin{array}{c}0.21 \\
14.77\end{array}$ & $\begin{array}{l}0.8131 \\
\mathbf{0 . 0 0 0 3}\end{array}$ & BB & $\begin{array}{c}\text { Physical state } \\
\text { Latitude } \\
\text { Error }\end{array}$ & $\begin{array}{c}2 \\
1 \\
74\end{array}$ & $\begin{array}{l}9.08 \\
9.01\end{array}$ & $\begin{array}{l}0.0003 \\
0.0036\end{array}$ \\
\hline DON & $\begin{array}{l}\text { Physical state } \\
\text { Latitude } \\
\text { Error }\end{array}$ & $\begin{array}{c}2 \\
1 \\
72\end{array}$ & $\begin{array}{c}1.96 \\
1.712\end{array}$ & $\begin{array}{l}0.145 \\
0.195\end{array}$ & $\mu$ & $\begin{array}{c}\text { Physical state } \\
\text { Latitude } \\
\text { Error }\end{array}$ & $\begin{array}{c}2 \\
1 \\
74\end{array}$ & $\begin{array}{l}12.55 \\
12.75\end{array}$ & $\begin{array}{c}<0.0001 \\
0.0006\end{array}$ \\
\hline
\end{tabular}



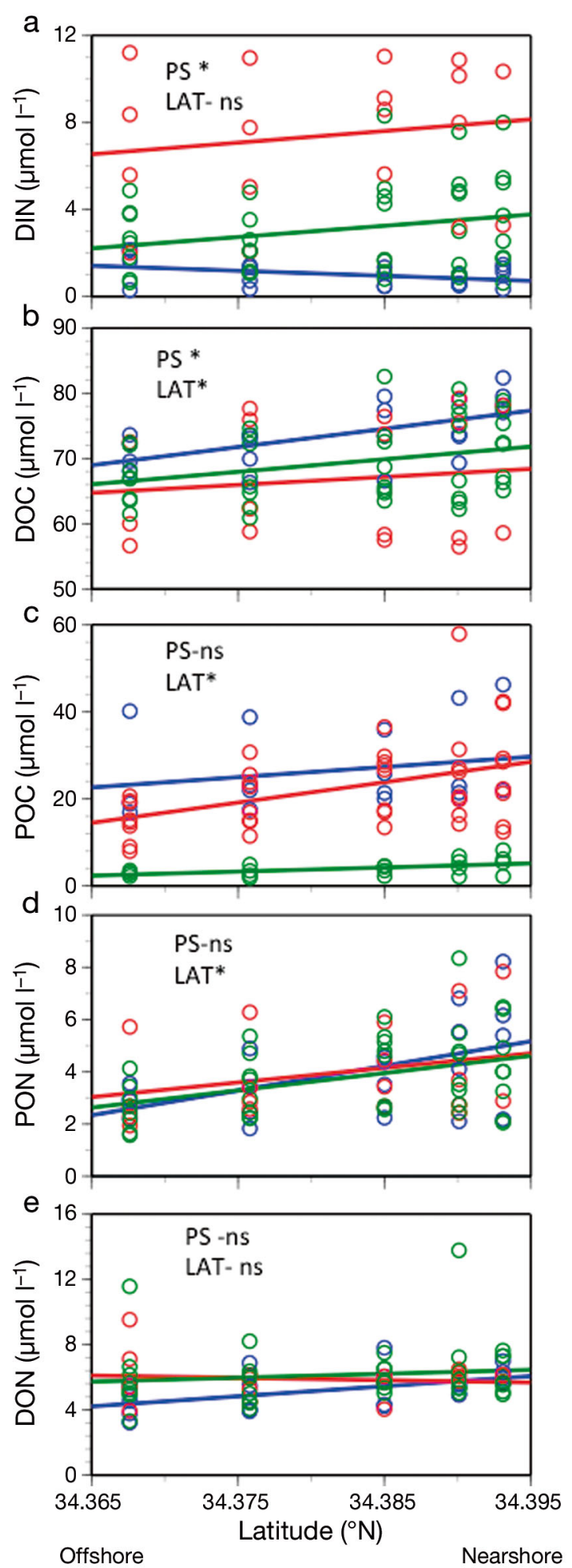
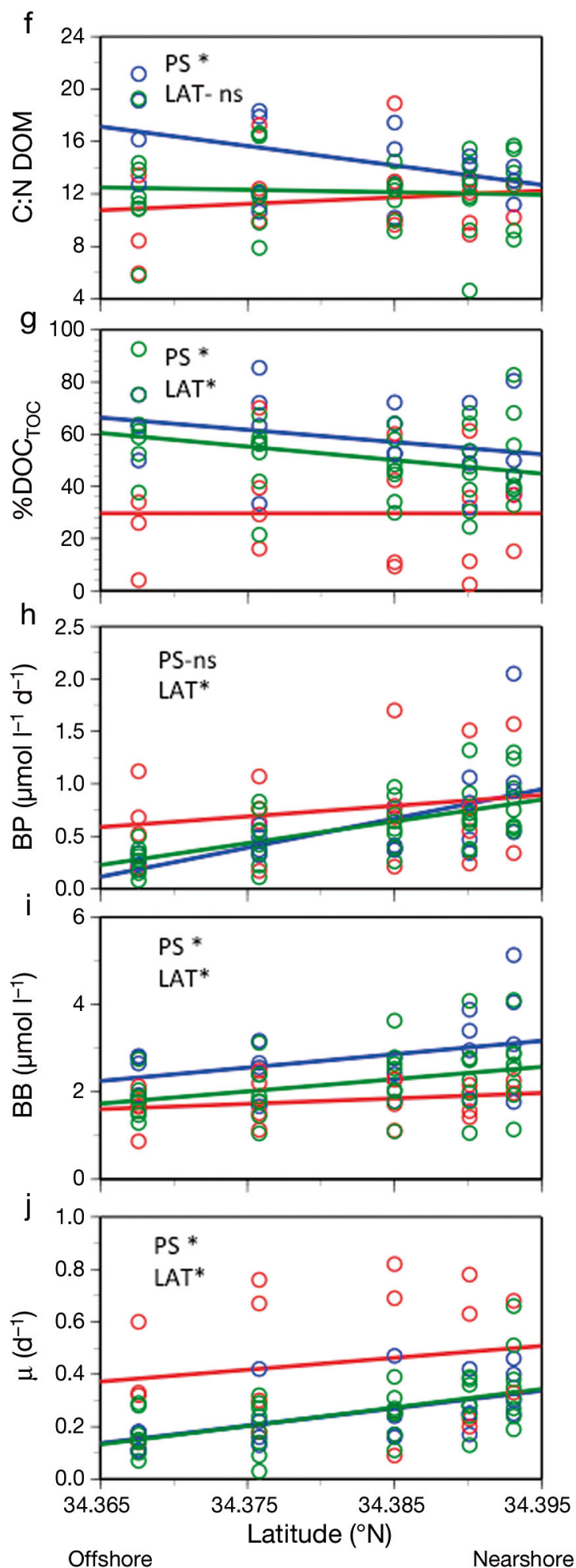

Fig. 5. Regression plots evaluating the cross shelf gradients for (a) DIN, (b) DOC, (c) POC, (d) PON, (e) DON, (f) C:N ratio of dissolved organic matter $(\mathrm{DOM}),(\mathrm{g}) \% \mathrm{DOC}_{\mathrm{TOC}}$ (i.e. percentage of the total accumulated organic carbon pool partitioned as DOC), (h) bacterial production (BP), (i) bacterial biomass (BB), and (j) bacterial specific growth rate ( $\mu$ ). Because the interaction effects in each ANCOVA were not significant, we cannot resolve the differences in cross shelf gradients between seasons; however, the regression lines are present for qualitative evaluation of trends. The color of the regression lines and symbols represent data from the various physical states including upwelling (red), weakly stratified (green), and strongly stratified (blue). The effect test of the independent variables (PS) physical state and (LAT) cross shelf gradient are identified as significant $\left({ }^{*}\right)$ or non-significant (ns). Further evaluation of the ANCOVA statistics are presented in Table 2. See Table 1 for other 
Table 3. Restricted maximum likelihood multivariate correlation analysis of biological and biogeochemical parameters (abbreviations as in Table 1, Fig. 5) from all stations and time points throughout the study. All parameters, except PP, were integrated ( 7 to $10 \mathrm{~m}$ ) and normalized by integration depth prior to correlation analysis. Values in the table are Pearson's product moment (r) values that are significant at $\mathrm{p}<0.05$; ns: not significant. Highly correlated values $(>0.5)$ are in bold

\begin{tabular}{|c|c|c|c|c|c|c|c|c|c|c|c|}
\hline & DOC & DON & POC & PON & C:N DOM & C:N POM & $\mathrm{PP}$ & $\mathrm{BP}$ & $\mathrm{BB}$ & $\mu$ & $\% \mathrm{DOC}_{\mathrm{TOC}}$ \\
\hline DIN & -0.65 & 0.29 & -0.17 & -0.30 & -0.48 & 0.59 & 0.22 & -0.15 & -0.43 & ns & -0.53 \\
\hline DOC & & -0.17 & 0.46 & 0.53 & 0.47 & -0.34 & -0.13 & 0.54 & 0.45 & 0.39 & 0.39 \\
\hline DON & & & ns & -0.11 & -0.85 & 0.34 & ns & ns & -0.17 & ns & -0.16 \\
\hline POC & & & & 0.97 & 0.13 & ns & 0.52 & 0.80 & 0.62 & 0.40 & -0.51 \\
\hline PON & & & & & 0.20 & -0.15 & 0.52 & 0.80 & 0.67 & 0.38 & -0.41 \\
\hline C:N DOM & & & & & & -0.40 & -0.14 & 0.12 & 0.24 & 0.04 & 0.35 \\
\hline C:N POM & & & & & & & 0.05 & ns & -0.26 & 0.10 & -0.55 \\
\hline PP & & & & & & & & 0.46 & 0.33 & 0.10 & -0.62 \\
\hline $\mathrm{BP}$ & & & & & & & & & 0.52 & 0.65 & -0.25 \\
\hline $\mathrm{BB}$ & & & & & & & & & & -0.12 & -0.13 \\
\hline$\mu$ & & & & & & & & & & & -0.10 \\
\hline
\end{tabular}

$\triangle \mathrm{DOC}$ and $\triangle \mathrm{POC}$ were determined by subtracting a constant annual low (background) value from the observed integrated and depth normalized measurements (see 'Materials and methods'); thus, the statistical results for $\triangle \mathrm{DOC}$ and $\triangle \mathrm{POC}$ are identical to those for DOC and POC (Fig. 5b,C, Table 2). $\triangle \mathrm{DOC}$ values show that the accumulation of DOC was strongest at the nearshore station (Stn 5) with $\triangle \mathrm{DOC}$ reaching up to $26 \mu \mathrm{M} \mathrm{C}$. $\triangle \mathrm{POC}$ and $\triangle \mathrm{DOC}$ began increasing in the later part of the spring 2008 upwelling period and remained elevated through December 2008 (Fig. 6a,b). The significant cross-shelf gradients in $\triangle \mathrm{DOC}$ resulted in spatial and temporal changes in the partitioning of the seasonally accumulated OM.

\section{Partitioning of $\mathrm{OM}$ between dissolved and particulate phases}

Radiocarbon tracer was used to assess the partitioning of $\mathrm{OM}$ from daily primary production by tracing ${ }^{14} \mathrm{C}-\mathrm{PP}$ released as $\mathrm{DO}^{14} \mathrm{C}$ (i.e. ER). ER rates

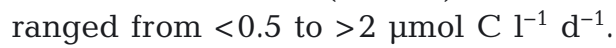
Interestingly, ER was only weakly correlated to PP (Table 4), with maximal ER rates following maximal PP rates by several months (Fig. 7a). ER reached maximal rates in June 2008 when the water column was first observed to be strongly stratified and depleted in DIN. During the strongly stratified period, nutrients remained depleted, and the magnitude of ER decreased (Fig. 7a), but its contribution to total $\mathrm{PP}$, i.e. PER, reached values as high as $45 \%$. PER was negatively correlated with the magnitude of PP

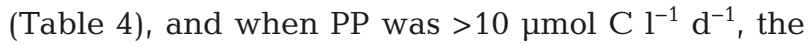
PER values fell below $15 \%$. Thus, elevated PER was a function of decreased overall PP relative to ER rather than increased rates of ER during this period.

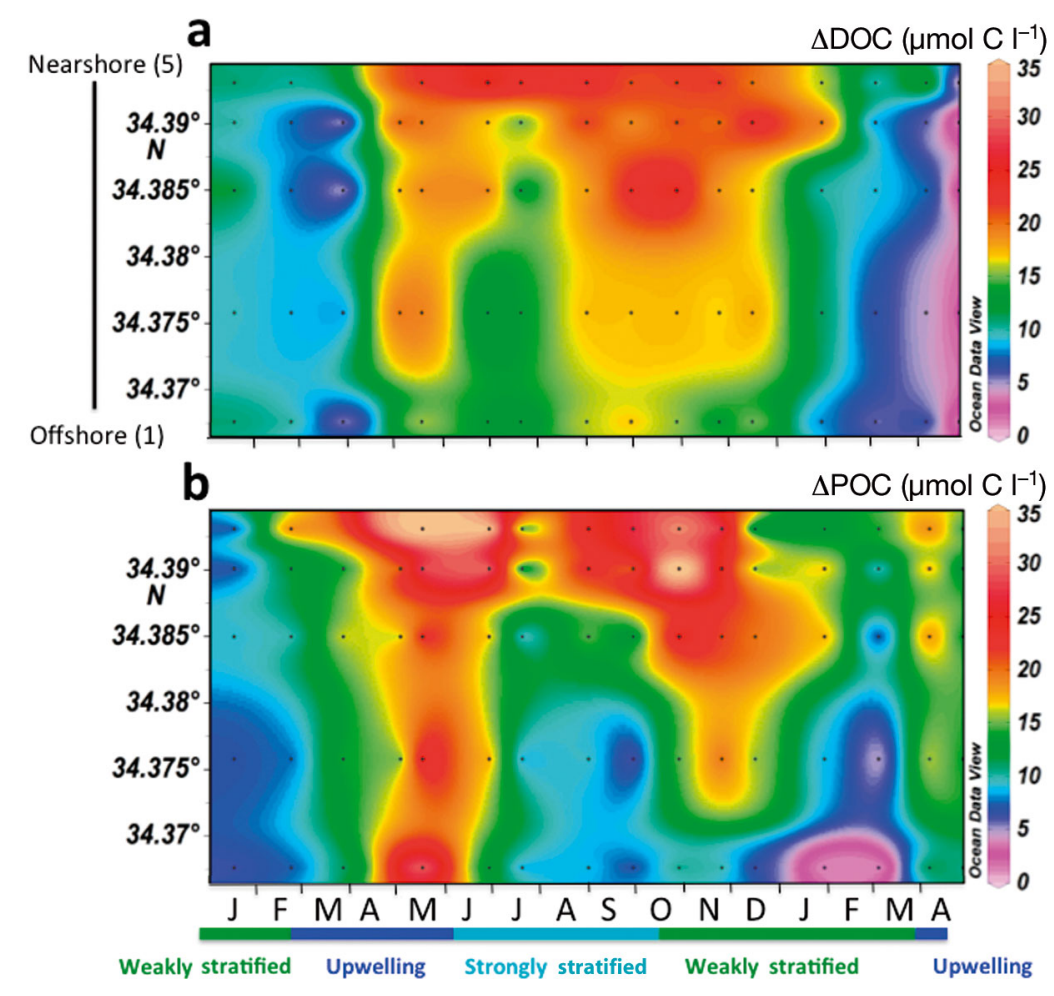

Fig. 6. Surface map of the integrated and depth-normalized inventories of seasonally accumulated dissolved (DOC) and particulate (POC) organic carbon above seasonal low concentrations presented as (a) $\triangle \mathrm{DOC}$ and (b) $\triangle \mathrm{POC}$ across the 5 stations within the inner shelf region of the Santa Barbara Channel from January 2008 to April 2009 
Table 4. Restricted maximum likelihood multivariate correlation analysis of rate and biogeochemical parameters (abbreviations as in Table 1, Fig. 5) measured at the $5 \mathrm{~m}$ depth throughout the study. Values in the table are Pearson's product moment (r) values that are significant at $\mathrm{p}<0.05$; ns: not significant. Highly correlated values $(>0.5)$ are in bold. ER: extracellular release from PP; PER: percent ER

\begin{tabular}{|c|c|c|c|c|c|c|c|c|}
\hline & $\mathrm{BP}$ & $\mu$ & ER & PER & $\triangle \mathrm{DOC}$ & $\triangle \mathrm{POC}$ & $\% \mathrm{DOC}_{\mathrm{TOC}}$ & DIN \\
\hline PP & 0.40 & ns & 0.30 & -0.58 & -0.19 & 0.47 & -0.61 & 0.37 \\
\hline $\mathrm{BP}$ & & 0.74 & 0.31 & -0.24 & 0.52 & 0.68 & -0.15 & ns \\
\hline$\mu$ & & & ns & -0.14 & 0.42 & 0.26 & ns & ns \\
\hline ER & & & & 0.37 & ns & 0.37 & -0.34 & ns \\
\hline PER & & & & & ns & -0.27 & 0.41 & -0.35 \\
\hline$\triangle \mathrm{DOC}$ & & & & & & 0.40 & 0.45 & -0.59 \\
\hline$\triangle \mathrm{POC}$ & & & & & & & -0.52 & -0.13 \\
\hline$\% \mathrm{DOC}_{\mathrm{TOC}}$ & & & & & & & & -0.53 \\
\hline
\end{tabular}

OM partitioning was also examined through direct measures of DOC and POC concentrations. The ratio of $\triangle \mathrm{DOC}$ to the sum of $\triangle \mathrm{DOC}$ plus $\triangle \mathrm{POC}$ $\left(\% \mathrm{DOC}_{\mathrm{TOC}}\right)$ was used to assess how accumulated OM was partitioned during various physicochemical states of the environment. This approach integrates processes that occur on longer time scales compared to measurements of the daily rates of DOC

a

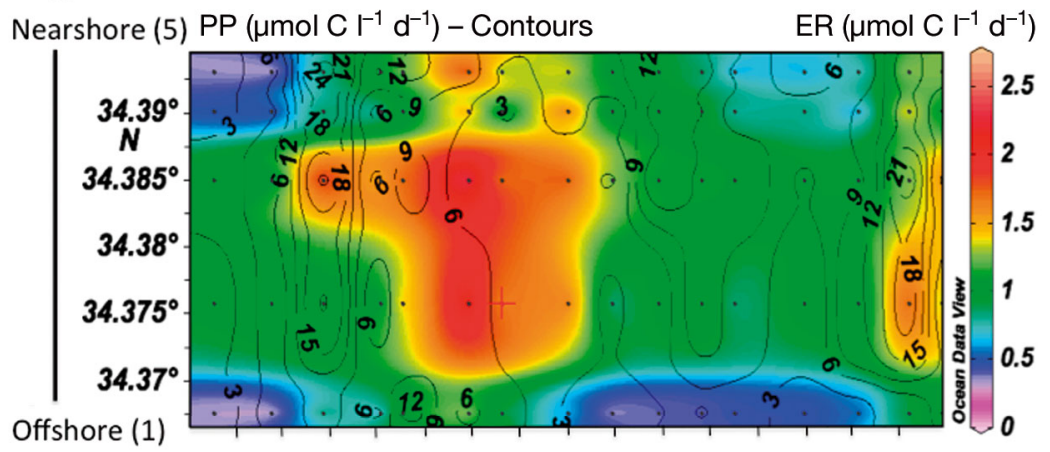

b

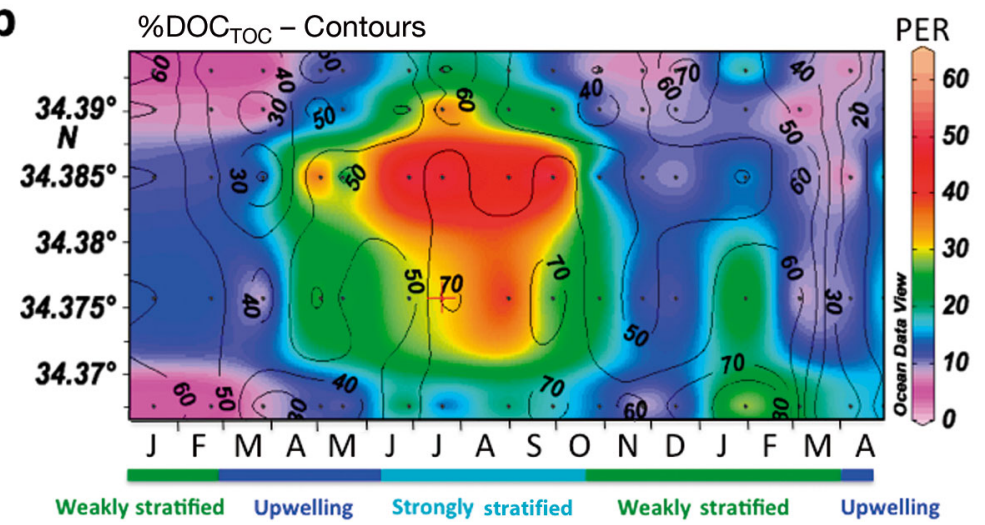

Fig. 7. Surface map of (a) extracellular release rates (color shading) and primary production (PP; contour line) and (b) percent ER (PER; color shading) and $\% \mathrm{DOC}_{\mathrm{TOC}}$ (contour line), which represents the percentage of the total accumulated organic carbon pool partitioned as DOC, measured at $5 \mathrm{~m}$ for all stations and time points release using the radioactive tracer technique. Changes in \%DOC ${ }_{\text {TOC }}$ were significantly different among physical states (Table 2). The initiation of upwelling in both years resulted in $\% \mathrm{DOC}_{\mathrm{TOC}}$ of $<40 \%$, indicating that the majority of newly produced OM was retained as particles during periods of high PP associated with upwelling (Fig. 7b). During periods of both weak and strong stratification, $\%$ DOC $_{\text {TOC }}$ was generally $>50 \%$. Significant cross-shelf gradients were also observed, with a greater percentage of OM partitioned into DOC for the offshore stations relative to nearshore (Figs. $5 \mathrm{~g} \& 7 \mathrm{~b}$, Table 2). These dynamics resulted in a significant negative correlation between $\%$ DOC $_{\text {TOC }}$ and both DIN (r = -0.53) and PP ( $\mathrm{r}=-0.62)$ (Table 3$)$. Although trends in \% ${ }^{\mathrm{DOC}} \mathrm{TOC}_{\mathrm{TO}}$ and $\mathrm{PER}$ address changes on very different timescales, there was a significant positive correlation between $\mathrm{PER}$ and $\% \mathrm{DOC}_{\mathrm{TOC}}$ $(\mathrm{r}=0.41)$ (Fig. 7b, Table 4) in the present study, suggesting that phytoplankton exudation was important to OM partitioning. However, ER and $\triangle \mathrm{DOC}$ were not correlated (Table 4), suggesting that the bioavailability of ER is variable, and during some periods (i.e. upwelling), a larger fraction of ER may be highly labile and readily consumed rather than accumulating as DOC.

\section{Bacterioplankton dynamics}

The seasonal dynamic of BP was highly variable with no statistically 
significant trends observed among the 3 physical states (Table 2). Cross-shelf gradients in BP were significant, with greater productivity observed nearshore (Fig. 5h, Table 2). However, spatial distributions of BP revealed fairly uniform production

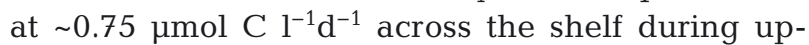
welling (Fig. 8a). Cross-shelf gradients appeared to be more pronounced during both strongly stratified and weakly stratified periods but could not be resolved statistically. There was a notable temporal offset between the PP and BP maxima, with BP lagging $\mathrm{PP}$ by $\sim 1$ to 2 mo (maximum in $\mathrm{PP}$ and $\mathrm{BP}$ occurring in March and April/May, respectively) (Figs. 7a \& 8a). BP was highly correlated with

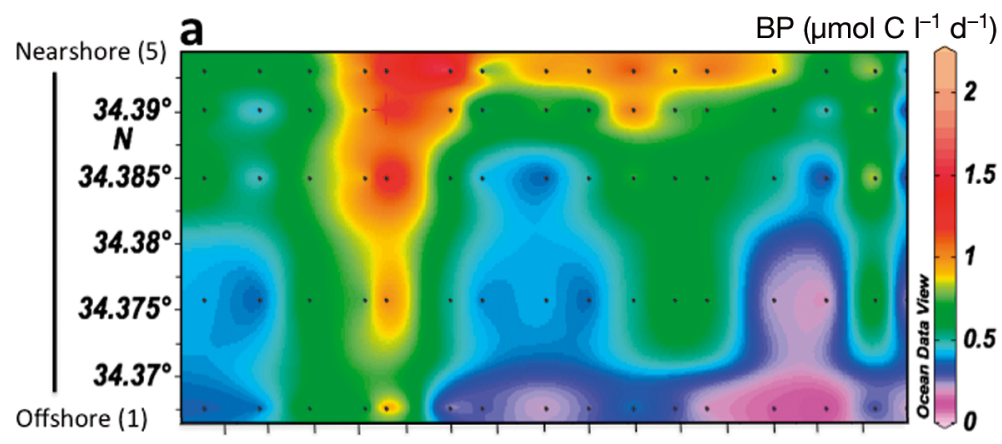

b $\mathrm{BB}\left(\mu \mathrm{mol} \mathrm{C} \mathrm{^{-1 } )}\right.$
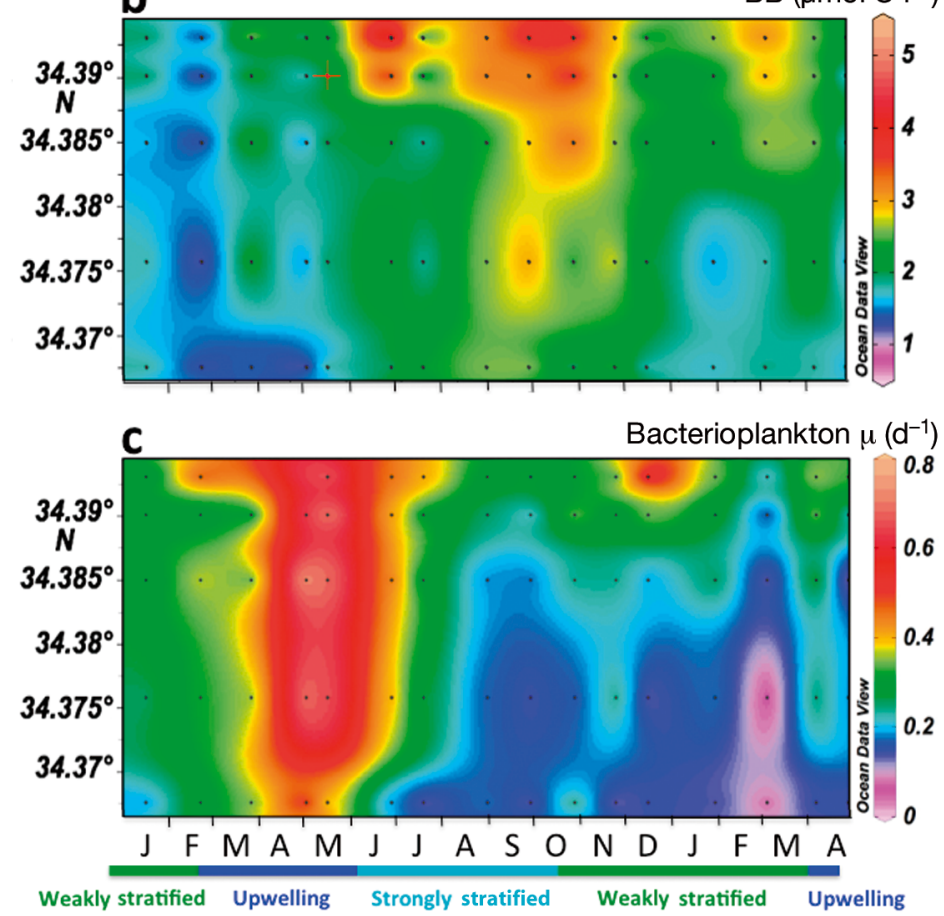

Fig. 8. Surface map of the integrated and depth normalized patterns in (a) bacterial production (BP), (b) bacterial biomass (BB), and (c) bacterial specific growth rate $(\mu)$ across 5 stations within the inner shelf region of the Santa Barbara Channel from January 2008 to April 2009. $\mu$ is calculated as BP / BB changes in POM $(\mathrm{r}=0.8$; for $\mathrm{POC}$ and $\mathrm{PON})$ and less so with DOC $(\mathrm{r}=0.54)$ concentrations (Table 3), suggesting that solubilization of POM to bioavailable DOM may have been important in this nearshore system. The maxima in BP preceded the maximum in BB by several months.

BB was significantly higher during the strongly stratified period $\left(\right.$ mean $=2.8 \mu \mathrm{mol} \mathrm{Cl^{-1 }}$ ) compared to the weakly stratified and upwelling conditions, which were not significantly different (mean $=26.5$ and $21.7 \mu \mathrm{mol} \mathrm{C} \mathrm{^{-1 }}$, respectively) (Table 2; followed by Tukey post hoc test, $\alpha=0.05$ ) (Fig. 8b). Spatial gradients for BB were enhanced nearshore and declined offshore (Figs. 5i \& 8b, Table 2).

Despite low bacterioplankton biomass during upwelling, the specific growth rates $(\mu)$ showed strong significant maxima during upwelling periods (mean $=0.45 \mathrm{~d}^{-1}$ ) in April and May 2008 compared to weakly stratified and strongly stratified conditions (mean $=0.25 \mathrm{~d}^{-1}$ for each) (Table 2, followed by Tukey post hoc test, $\alpha=0.05$ ) with values generally $>0.5 \mathrm{~d}^{-1}$ and as high as $0.9 \mathrm{~d}^{-1}$ in May 2008. Cross-shelf gradients in $\mu$ where also observed (Figs. 5j \& 8c, Table 2), with greater rates at the most nearshore station relative to offshore stations (Fig. 8c). Interestingly, there was a decoupling between $\mu$ and bacterial biomass, with bacterial biomass building up across the shelf despite low $\mu$. The summer maximum in BB in the absence of high $\mu$ indicates that top-down controls were reduced, allowing cells to accumulate.

\section{DOC bioavailability}

Enhanced BP during upwelling may be related to the elevated ER rates observed at that time. However, the BP and ER rates became uncoupled after nutrients were depleted under strong stratification, perhaps indicating a change in the quality of the ER to forms not instantaneously available for BP. The microbial remineralization experiments support this conclusion. Bioavailable DOC comprised the highest fraction of the DOC pool in May 2008, coincident with the late phase of upwelling and immediately following periods of elevated PP and high ER rates.

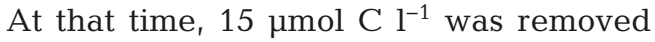


within $1 \mathrm{wk}$, corresponding to $18 \% \mathrm{BDOC}$, on the

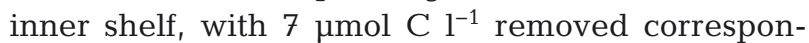
ding to $9 \%$ BDOC on the outer shelf (Fig. 9, Table 5). However, remineralization bioassay experiments conducted in late June when nutrients were

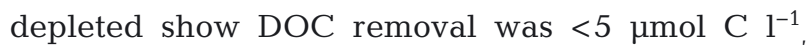
equating to $\sim 5 \%$ BDOC within the first week of the experiments for both the offshore and nearshore stations despite being conducted during a time when ER rates were maximal (Figs. $7 \&$ 9, Table 5). These experiments indicate that the quality of DOM produced was more labile during the upwelling condition than under weakly or strongly stratified conditions.

BGE during the first week of the incubation in the remineralization experiments averaged $27 \pm 16 \%$ for all experiments. There appeared to be a general trend in which the mean BGE at offshore Stn 1 was higher $(35 \pm 17 \%)$ compared to Stn 5 on the inner shelf $(19 \pm 11 \%$; Table 5$)$; however, statistically significant differences (1-way ANOVA, $F_{1,8}=3.06, \mathrm{p}=$ 0.12 ) were not resolved due to the limited number of experiments and associated variability.

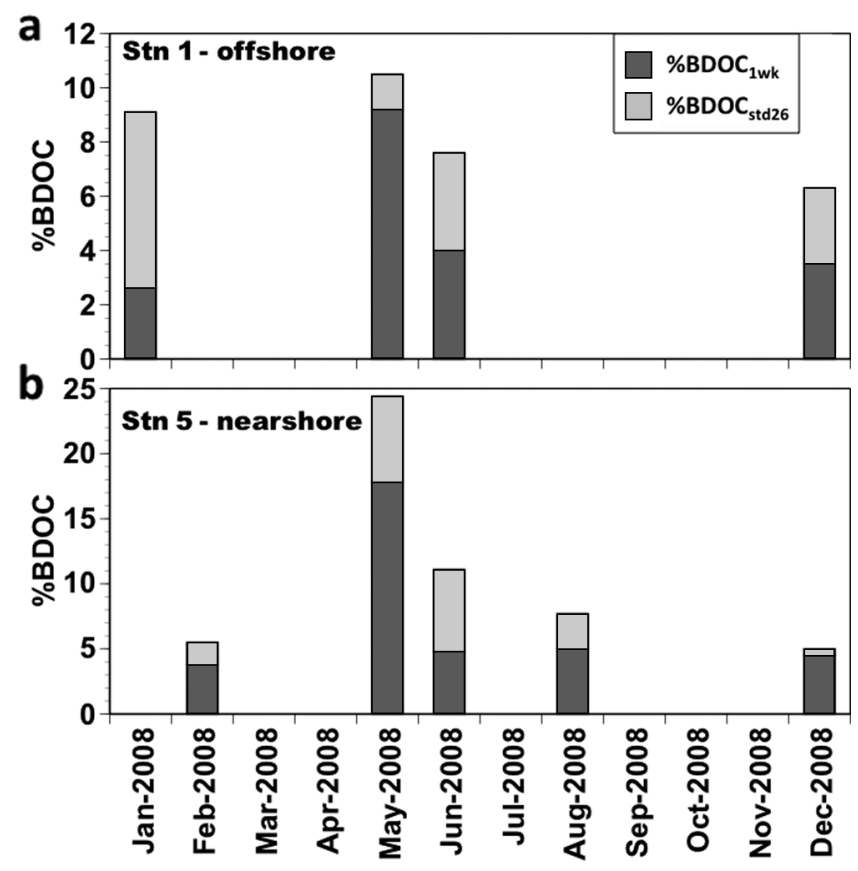

Fig. 9. Percent bioavailability of dissolved organic carbon (\%BDOC) in seawater cultures measured within $1 \mathrm{wk}$ of the incubation (\% $\mathrm{BDOC}_{1 \mathrm{wk}}$ dark grey bars) and between $1 \mathrm{wk}$ and $26 \mathrm{~d}$ of incubation (\%DOC $\mathrm{Dtd}_{\text {st }}$; light grey bars) at the (a) offshore and (b) inner-shelf stations of the cross-shelf transect. The long-term DOC removal was standardized to $26 \mathrm{~d}$ for comparative purposes (see text for details). This figure only presents experiments in which both short- and longterm DOM removal were resolved. See Table 5 for further details

\section{DISCUSSION}

\section{Partitioning of OM with shifts in physical state}

The present study is unique in that it tracks the partitioning of OM between the dissolved and particulate phases using both short-term radiotracer experiments and temporal trends in bulk organic constituents over an entire year in a coastal system under both high and low nutrient conditions. The sampling scheme allowed cross-shelf gradients to be resolved through the annual cycle, but the apparent temporal changes along the transect are also strongly influenced by advection. Persistent poleward alongshore flow dominates the mainland shelf in the SBC, with surface current velocities of up to tens of kilometers per day (Harms \& Winant 1998, Ohlmann et al. 2007, Fram et al. 2008). This flow intensifies in summer, possibly restricting cross-shelf exchange (Harms \& Winant 1998, Fram et al. 2008), facilitating the evolution of cross-shelf gradients in chemical (DOC, POC, and $\mathrm{PON}$ ) and bacterioplankton parameters in the SBC. Thus, differences among sequential dates do not represent a true temporal change; however, changes in dynamics relative to the seasonal evolution of water column stratification are likely robust.

Partitioning of OM was assessed by comparing the $\mathrm{DO}^{14} \mathrm{C}$ production rates to total PP rates (i.e. short time scales) and by comparing changes in concentrations of accumulated DOC and POC (i.e. integration over longer temporal scales). The magnitude of ${ }^{14} \mathrm{C}$ $\mathrm{PP}$ released as $\mathrm{DO}^{14} \mathrm{C}$, i.e. $\mathrm{ER}$, can provide insight into OM partitioning and the relative importance of direct phytoplankton release to changes in the bulk DOC pool. PER is typically measured at $~ 5 \%$ (typical range 2 to $10 \%$ ) in experimental cultures of a variety of marine phytoplankton species growing in exponential phase (e.g. Nagata 2000). In field experiments across numerous aquatic ecosystems, PER is wide ranging but with values typically greater than those observed in exponentially growing cultures. Carlson (2002) reviewed 34 studies of marine ecosystems and showed that a mean value of $22 \%$ is typical, with a range of 5 to $55 \%$. Throughout much of the present study, we observed PER values similar to that reported by Sintes et al. (2010) for the coastal North Sea (i.e. 1 to $14 \%$ ) and Baines \& Pace (1991) cross system estimate $(13 \%)$. However, at the end of upwelling and during the initial periods of strong stratification, PER reached values of $45 \%$ and persisted at high values for several months (Fig. 7b). PER was significantly correlated with the $\% \mathrm{DOC}_{\mathrm{TOC}}$ consistent with phytoplankton exudation as a me- 


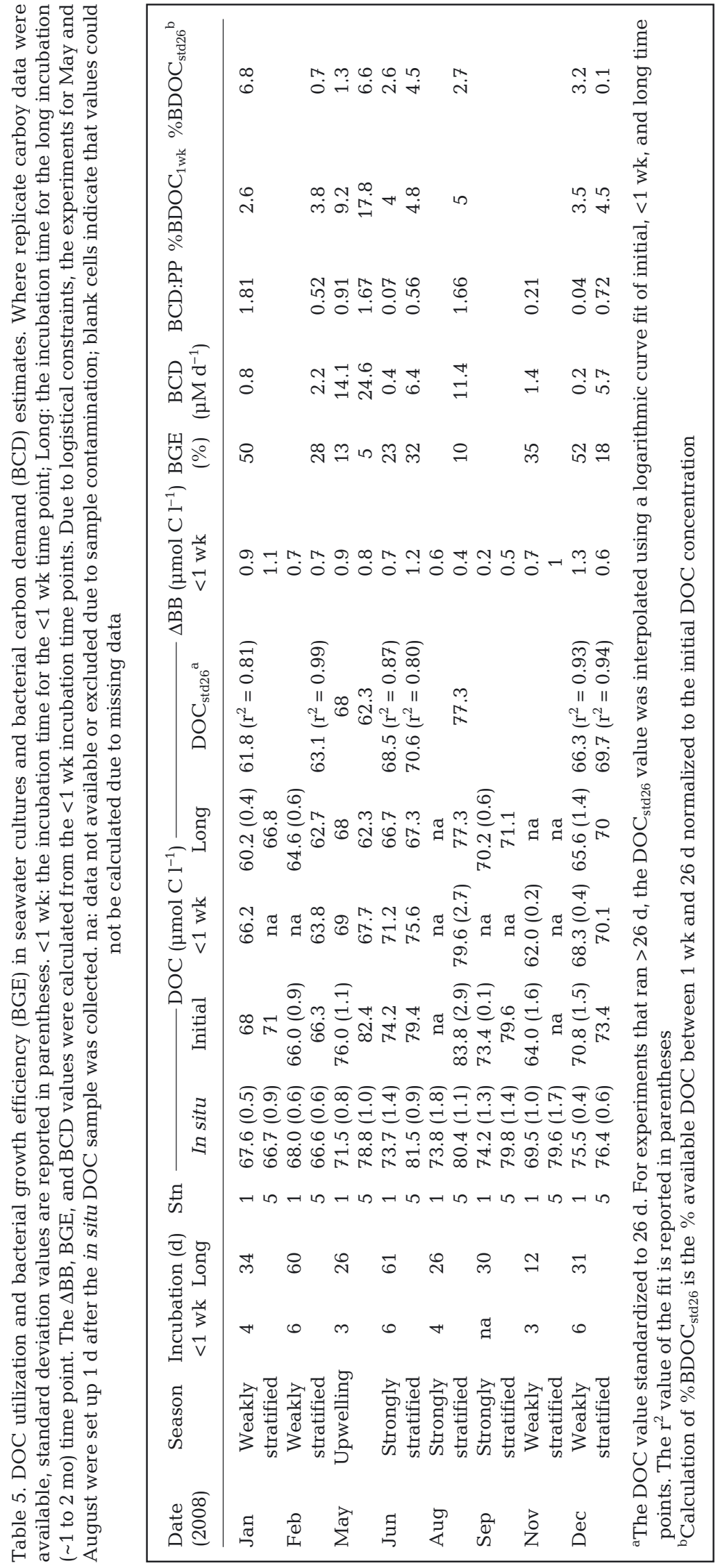

chanism leading to DOC accumulation (Table 4, Fig. 7b), but interestingly, no significant correlations between PER or ER and $\triangle$ DOC (Table 4) were observed. Thus, while PER may be enhanced during periods of nutrient depletion, the absolute magnitude of ER was inadequate to account for the DOC accumulation during most of the stratified period.

The lack of a strong relationship between measures of phytoplankton exudation and $\triangle \mathrm{DOC}$ is not necessarily unexpected. The contributions of PER and ER to $\triangle \mathrm{DOC}$ are likely obfuscated by the vastly different time scales addressed by each measurement. PER and ER represent processes occurring over hours during the single day each month when sampling was conducted, while $\triangle \mathrm{DOC}$ integrates over much longer time scales and captures the cumulative effects of processes not represented in the PER and ER measurements (Sintes et al. 2010). PER and ER address a limited number of processes associated with the release of DOM by phytoplankton, while $\triangle \mathrm{DOC}$ reflects the net result of all biological, chemical, and environmental factors that control the production of DOM and its consumption. Thus, PER and ER serve as indices of when DOM exudation by phytoplankton is most pronounced, but their utility in constructing biogeochemical budgets is limited. Despite that limitation, the observed sequence of high PP during upwelling followed by elevated ER with nutrient depletion followed by a maximum in PER under the persistently low nutrient conditions in stratified waters matches the dynamics predicted from laboratory phytoplankton culture experiments under different phases of growth (Obernosterer \& Herndl 1995) and represents one of the first sets of coupled short-term and long-term OM partitioning in coastal systems.

The pronounced seasonal shifts in the partitioning of OM between the dissolved and particulate phases were highly negatively correlated to nutrient availability (Table 3). Our data show that $>60 \%$ of the OM accumulating during the high-nutrient conditions associated with the spring bloom was retained as particles. Both PER and $\% \mathrm{DOC}_{\mathrm{TOC}}$ were negatively correlated with 
PP (Table 4), consistent with previous studies that suggest that when phytoplankton are in a physiological healthy state, the majority of the OM is retained in a particulate phase (Carlson et al. 1998, Smith et al. 1998, Nagata 2000, Carlson \& Hansell 2003, Wetz \& Wheeler 2003). The situation reversed as upwelling relaxed, the water column became stratified, and macronutrients became depleted, resulting in an increase in $\% \mathrm{DOC}_{\mathrm{TOC}}$ to $70 \%$ (Fig. 7b). This shift in OM partitioning is consistent with past field experiments in other coastal systems (Williams 1995, Doval et al. 1997, Wetz \& Wheeler 2003), observations within nutrient-amended coastal mesocosms (Smith et al. 1998, Søndergaard et al. 2000, Wetz \& Wheeler 2003), and field experiments in oligotrophic systems (Copin-Montegut \& Avril 1993, Carlson et al. 1998, Hansell \& Carlson 2001), supporting the idea that nutrient-driven seasonal shifts in OM partitioning are characteristic of much of the temperate and subtropical ocean (Williams 1995, Carlson et al. 1998).

Past suggestions that DOM with high a $\mathrm{C}: \mathrm{N}$ ratio is less susceptible to rapid microbial degradation (Williams 1995) are supported by our observation of the accumulation of $\mathrm{C}$-rich DOM with $\mathrm{C}: \mathrm{N}$ ratios, generally $>13$ (Fig. 4a), and low \%BDOC during nutrient-depleted stratified conditions (Fig. 9). Our data show C-rich DOM accumulating following DIN depletion (Williams 1995) possibly due to the induction of a DOC overflow mechanism in phytoplankton cells as they transitioned from nutrient-replete to nutrient-deplete conditions, ridding the phytoplankton cells of excess carbon (Bjørnsen 1988, Goldman et al. 1992, Sambrotto et al. 1993). It is also possible that photochemical reactions due to exposure of newly produced DOC to UV could increase DOM recalcitrance. Tranvik \& Bertilsson (2001) demonstrated that when recently produced algal exudates were exposed to UV, some portion of the biomolecules undergo photochemical condensation reactions, making them less available to bacterial hydrolysis and thus accumulated in the DOM pool.

\section{Cross-shelf trends}

Spatial gradients were demonstrated for DOC, POC, and bacterial parameters with the overall trend showing decreasing concentrations and rates from nearshore to offshore (Figs. 3, 5 \& 8). The lack of a significant interaction term in ANCOVA analyses precludes us from statistically resolving spatial gradients between physical states; however, qualitatively weak spatial gradients in $\mathrm{DOC}, \mathrm{BP}$, and $\mathrm{BB}$ along this transect during periods of upwelling suggest exchange between the inner-shelf and offshore waters at these times. When upwelling relaxes and stratification of the water column ensues, the inner shelf becomes more isolated from offshore influences and appears to result in steeper gradients of DOC, BP, and BB (Figs. 3, 5 \& 8).

The observation that cross-shelf gradients in DOC and BP persist for months under stratified conditions suggests that these gradients are a common feature of shelf waters advecting along the coast during summer and fall. The spatial extent of these features along the coast may be large at least for some properties, such as phytoplankton biomass, leading Lucas et al. (2011) to coin the phrase 'the green ribbon' for a semi-coherent zone of high phytoplankton biomass that persists on the inner shelf over much of the California Bight. The accumulation of microbially resistant DOM during stratified periods has biogeochemical significance. If DOM accumulates in the inner shelf and resists rapid microbial degradation, this DOM can persist and eventually be advected to offshore environments, removing carbon and nitrogen from the inner shelf system, and can influence the carbon mass balance of surrounding waters (Williams 1995, Peltzer \& Hayward 1996).

\section{Bacterioplankton dynamics}

BP lagged phytoplankton PP and may be related to the reduced ER and PER during periods when the phytoplankton were in healthy exponential growth (see studies reviewed by Nagata 2000, Carlson 2002). Alternatively, the temporal offset between the peaks in phytoplankton and bacterial productivity in spring 2008 may be related to the time necessary for the hydrolysis of larger macromolecules (Hoppe et al. 2002 ) to compounds $\leq 600$ Da that can be taken up by bacteria (Weiss et al. 1991). Billen (1990) assigned the delayed response of bacterioplankton production with respect to phytoplankton production to the release of macromolecular compounds by postmortem lysis of algal cells near the end of phytoplankton blooms. We note, however, that bacterial specific growth rates were enhanced during the upwelling period, suggesting that although biomass was low, the bacterioplankton community was responding to a supply of labile substrates that were apparently turning over relatively quickly (Fig. 8c). This is coincident with periods when ER rates were elevated and DIN was replete. 


\section{Bioavailability of DOC and associated BGE}

The range in \%BDOC measured in our study (Table 5) is comparable to that reported for other coastal studies (Søndergaard \& Middelboe 1995, Lønborg \& Søndergaard 2009, Lønborg et al. 2011), but our time series revealed a strong seasonal trend. The remineralization bioassays revealed that the bioavailability of DOC was greatest during upwelling (May 2008), when 7 to $15 \mu \mathrm{M}$ DOC was consumed over the course of $1 \mathrm{wk}$. At this time, the \%BDOC ranged from 9 to $18 \%$ on the outer and inner shelf, respectively (Table 5, Fig. 9). We attribute the enhanced removal during upwelling conditions to the greater availability of inorganic nutrients that could increase the quality of phytoplankton exudates (Williams 1995, Carlson \& Hansell 2003) and the enhanced ER rates that raised the availability of this high quality DOM.

The transition to strongly stratified conditions in June 2008 shifted \%BDOC downwards to $\sim 3$ to $5 \%$ over the course of $1 \mathrm{wk}$ (Fig. 9, Table 5). During this period, the \%BDOC removed for the nearshore and offshore stations (standardized to $26 \mathrm{~d}$ ) was comparable; however, for the offshore station, DOC removal in the remineralization bioassays generally occurred on time scales longer than 1 wk (Table 5, Fig. 9). The slower DOC removal rate suggests a shift in the quality of the OM available to heterotrophic communities under stratified conditions.

Our data do not allow us to discern the mechanism(s) leading to the decrease in DOM bioavailability following upwelling. However, the decrease in macronutrients following the onset of stratification at the same time as the C:N ratio of the DOM increased is consistent with previous work showing that bioavailability is influenced by DOM stoichiometry (Williams 1995), molecular size, and chemical composition (Amon \& Benner 1996, Amon et al. 2001, Goldberg et al. 2009). We cannot rule out the possibility that availability of inorganic nutrients limited $\mathrm{BP}$, resulting in DOM accumulation (Cotner et al. 1997, Thingstad et al. 1997, Obernosterer et al. 2003). However, inorganic nutrients, while low, were not below limits of detection and may not be limiting to bacterioplankton given their high surface area to volume ratio. It is also possible that extant microbial community structure capable of taking up DOM (Carlson et al. 2004) and the composition of phytoplankton producing DOM play a role in DOM availability.

Lomas \& Bates (2004) showed that the prevalence of haptophytes and prochlorophytes was positively correlated with enhanced accumulation of DOC in the oligotrophic Sargasso Sea and suggested that phytoplankton community structure may control the quality of DOM and whether or not DOM accumulates. Previous work with Phaeocystis spp. has also demonstrated significant DOM accumulation following blooms in the North Sea (Lancelot \& Mathot 1987 , Cadée \& Hegeman 2002, Sintes et al. 2010), indicating that the source of autotrophic high molecular weight DOM may resist rapid microbial degradation (Billen 1990) and accumulate. In the present study, there was a pronounced shift in phytoplankton assemblage from diatoms to dinoflagellates as upwelling relaxed and the water column became stratified (Goodman et al. 2012); however, additional controlled studies are needed to discern the linkage between phytoplankton community structure, available nutrient stoichiometry, and DOM production and quality.

Identifying the efficiency with which bacterioplankton are capable of utilizing DOM is fundamental to determining the role of bacterioplankton in controlling the fate of DOC. Decreases in BGE result in higher rates of remineralization and respiratory losses of carbon such that the same DOM pool produces less bacterial biomass, i.e. a sink to the microbial loop (Ducklow et al. 1986). Flagellate grazers were not enumerated in the present remineralization experiments. Thus, we cannot assess the impact of grazers in later stages of the remineralization experiments that could influence both DOC removal and measured BB. Despite this, BGE estimates (Table 5) and mean BGE values and seasonal variability is consistent with the coastal study of Sintes et al. (2010) for large and small free living bacterioplankton (35 and $27 \%$, respectively). The BGE estimates also fall within the range $(<10 \%$ to $>60 \%$ and mean $27 \pm 18 \%$ $\mathrm{SD}$, median $=25 \%$ ) reported for other coastal areas (del Giorgio \& Cole 1998, 2000). The annual average BGE of $27 \pm 16 \%$ on the Santa Barbara continental shelf suggests the respiration was, on average, $73 \%$ of the assimilated carbon by the bacterial community, resulting in low bacterial carbon transfer to higher trophic levels in this system.

BGE was related to physical state in an unusual way in the present study (Table 5), with lowest efficiencies (mean $<10 \%$ ) observed during the upwelling period and higher efficiencies associated with stratified periods (mean $30 \pm 14 \% \mathrm{SD}$ ). This pattern is surprising because during upwelling, the combination of nutrient enrichment, high $\mathrm{PP}$, and highly bioavailable organic substrates would be expected to support high BGE (del Giorgio \& Cole 1998). At the 
time the 'upwelling' remineralization bioassay experiments were conducted, the BP was enhanced across all of the stations. The modest BB at this time resulted in maximal specific growth rates observed during the present study (Fig. 8c). High specific growth rates in the absence of elevated $\mathrm{BB}$ are consistent with the low BGE observed in May 2008. Similar results of low BGE and high $\mu$ have been reported during early phases of phytoplankton blooms (Carlson \& Hansell 2003). The high flux of DOC may help to maintain a population in an 'energized physiological state' in which the population trades growth efficiency for the ability to exploit and respond to transient but favorable environmental conditions associated with patchiness of available OM (del Giorgio \& Cole 1998). It also may be related to the polymeric composition of the available DOM. For example, hydrolyses of large polymeric compounds may require the synthesis of enzymatic machinery, which is energetically costly for the bacterioplankton, resulting in low BGE (Billen 1990). Without further DOM characterization or enzymatic activity data, the reason for the low BGE during the upwelling state remains unclear.

BGE was independent of DOC concentrations as we observed both the lowest (May 2008) and highest BGE (June and December 2008) in periods when the accumulation of DOC above the seasonal low was $\sim 20 \mu \mathrm{M}$ C (Table 5, Fig. 6a). Thus, controls of BGE are complex and variable depending not only on the concentration of DOC but also on its source, composition (Lancelot \& Mathot 1987), and perhaps macronutrient availability (Teixeira de Mattos \& Neijssel 1997, del Giorgio \& Cole 1998).

Determinations of BGE combined with measurements of BP allowed us to estimate the amount of DOM required to support the observed bacterial biomass production (total bacterial C consumption, or BCD) (Carlson et al. 1998). Due to logistical constraints, remineralization experiments were conducted only at the extreme inshore and offshore stations within the upper $5 \mathrm{~m}$. These experiments are taken to represent processes within the upper $5 \mathrm{~m}$, i.e. within the mixed layer. Estimates of BCD for the SBC inner shelf (5 $\mathrm{m}$ depth) varied widely, ranging from 0.2 to $24.6 \mu \mathrm{mol} \mathrm{C}^{-1} \mathrm{~d}^{-1}$, with maximum demand in May 2008 at Stn 5 (Table 5). Comparing these values with phytoplankton PP (measured at $5 \mathrm{~m}$ ) provides an estimate of the percentage of PP that is required to support gross BP (expressed as the ratio BCD:PP). For most of our sampling dates, the measured PP in the surface water was sufficient to meet the BCD (BCD:PP < 1.0) (Table 5); however, during sampling periods in January, May, and
August 2008, BCD exceeded phytoplankton PP (BCD:PP > 1.0) (Table 5). BGE estimates and rates for $\mathrm{PP}$ were only measured in the upper $5 \mathrm{~m}$ during the present study; thus, we are unable to constrain the metabolic balance of the water column across the inner shelf of the SBC. Nevertheless, during the periods when BCD was greater than phytoplankton PP, estimates within the surface indicate that sources of DOC other than daily phytoplankton PP were used to support the BCD of the surface bacterioplankton community.

At this shallow coastal study site, we cannot ignore other inputs of OM from the benthos, terrestrial inputs, or those from the nearby giant kelp forest. Unlike other coastal studies where riverine input of DOM is large and sustained for long periods (Sintes et al. 2010), freshwater inputs to the SBC are extremely small due to the Mediterranean-like climate, and they are confined to the winter period with little effect on coastal nutrient dynamics outside of a few days following major storms (McPhee-Shaw et al. 2007). Beach pore waters of the SBC can contain millimolar concentrations of DOC (J. Dugan pers. comm.), and benthic DOC flux from coastal sediments can be large (i.e. $\mathrm{mmol} \mathrm{m}^{-2} \mathrm{~d}^{-1}$ ) (Burdige 2002); thus, benthic flux may be an important source of DOC to the water column of the inner shelf environment (Burdige 2002, Avery et al. 2012). Additionally, Santa Barbara coastal waters contain substantial stands of macroalgae, particularly the giant kelp Macrocystis pyrifera, growing on inner shelf rocky reefs in generally $<20$ m water depth (such as Mohawk reef, located at the inshore end of our sampling transect). Preliminary studies indicate that $\sim 30 \%$ of giant kelp net primary production is released as DOC and that some of this material is rapidly utilized by the local heterotrophic bacterioplankton community (E. Halewood unpubl. data). The seasonal pattern of kelp productivity (Reed et al. 2009) matches the pattern of inner shelf DOM accumulation in that productivity rises in spring and peaks in mid summer, suggesting a possible kelp derived source of inner shelf DOM.

\section{SUMMARY}

The data presented here represent the first findings with respect to the distribution and bioavailability of DOC on the Santa Barbara coastal shelf ecosystem over an entire annual cycle and the specifics of bacterial growth dynamics. There was significant temporal and spatial variability in distributions of inorganic and organic nutrients across the continen- 
tal shelf. OM production was largely partitioned into the particulate phase during upwelling, but as the water column stratified, DOC accumulation exceeded POC accumulation, leading to an accumulation of DOC on the inner shelf during summer. The bioavailability of the DOC pool to heterotrophic bacterioplankton and the efficiency of its use varied over time and space, with the highest lability during upwelling following the peak in PP and during high ER. This time-series approach allowed us to evaluate how partitioning of OM evolved under seasonally changing physical states and its effects on DOM lability and bacterioplankton dynamics.

Acknowledgements. We thank C. Nelson and D. Salazar for assistance in the field and R. Henry for technical assistance throughout the project. We thank C. E. Nelson for valuable discussion throughout the writing of this manuscript. This work was supported by the U.S. National Science Foundation's Long Term Ecological Research Program under the Division of Ocean Sciences grants OCE9982105 and OCE 0620276 to D.C.R. and OCE-0850857 to C.A.C. and M.A.B.

\section{LITERATURE CITED}

Amon RMW, Benner R (1996) Bacterial utilization of different size classes of dissolved organic matter. Limnol Oceanogr 41:41-51

> Amon RMW, Fitznar H, Benner R (2001) Linkages among the bioreactivity, chemical composition, and diagenetic state of marine dissolved organic matter. Limnol Oceanogr 46:287-297

> Avery GB, Kieber RJ, Taylor KJ, Dixon JL (2012) Dissolved organic carbon release from surface sand of a high energy beach along the southeastern coast of North Carolina, USA. Mar Chem 132-133:23-27

> Azam F, Fenchel T, Field JG, Gray JS, Meyer-Reil LA, Thingstad F (1983) The ecological role of water-column microbes in the sea. Mar Ecol Prog Ser 10:257-263

Baines SB, Pace ML (1991) The production of dissolved organic matter by phytoplankton and its importance to bacteria: patterns across marine and freshwater systems. Limnol Oceanogr 36:1078-1090

Billen G (1990) Delayed development of bacterioplankton with respect to phytoplankton: a clue for understanding their trophic relationships. Arch Hydrobiol Beih Ergeb Limnol 34:191-201

Bjørnsen PK (1988) Phytoplankton exudation of organic matter: Why do healthy cells do it? Limnol Oceanogr 33: 151-154

Brzezinski M, Washburn L (2011) Phytoplankton primary productivity in the Santa Barbara Channel: the effects of wind-driven upwelling and mesoscale eddies. J Geophys Res 116:C12013, doi:10.1029/2011jc007397

Burdige DJ (2002) Sediment pore waters. In: Hansell DA, Carlson CA (eds) Biogeochemistry of marine dissolved organic matter. Academic Press, San Diego, CA, p 611-663

Cadée GC, Hegeman J (2002) Phytoplankton in the Marsdiep at the end of the 20th century; 30 years monitoring biomass, primary production, and Phaeocystis blooms. J Sea Res 48:97-110
Campbell L (2001) Flow cytometric analysis of autotrophic picoplankton. In: Paul JH (ed) Methods in microbiology: marine microbiology. Academic Press, San Diego, CA, p 317-341

Carlson CA (2002) Production and removal processes. In: Hansell DA, Carlson CA (eds) Biogeochemistry of marine dissolved organic matter. Academic Press, San Diego, CA, p 91-151

Carlson CA, Hansell DA (2003) The contribution of dissolved organic carbon and nitrogen to biogeochemistry of the Ross Sea. In: DiTullio G, Dunbar R (eds) Biogeochemical cycles in the Ross Sea. AGU Press, Washington DC, p 123-142

Carlson CA, Ducklow HW, Hansell DA, Smith WO (1998) Organic carbon partitioning during spring phytoplankton blooms in the Ross Sea polynya and the Sargasso Sea. Limnol Oceanogr 43:375-386

> Carlson CA, Giovannoni SJ, Hansell DA, Goldberg SJ and others (2002) The effect of nutrient amendments on bacterioplankton production, community structure and DOC utilization in the northwestern Sargasso Sea. Aquat Microb Ecol 30:19-36

> Carlson CA, Giovanonni SJ, Hansell DA, Goldberg SJ, Parsons R, Vergin K (2004) Interactions among dissolved organic carbon, microbial processes, and community structure in the mesopelagic zone of the Northwestern Sargasso Sea. Limnol Oceanogr 49:1073-1083

> Carlson CA, Hansell DA, Nelson NB, Siegel DA and others (2010) Dissolved organic carbon export and subsequent remineralization in the mesopelagic and bathypelagic realms of the North Atlantic basin. Deep-Sea Res II 57: 1433-1445

Collins CA, Garfield N, Rago TA, Rischmiller FW, Carter E (2000) Mean structure of the inshore countercurrent and California undercurrent off Point Sur, California. DeepSea Res II 47:765-782

Copin-Montegut G, Avril B (1993) Vertical distribution and temporal variation of dissolved organic carbon in the northwestern Mediterranean Sea. Deep-Sea Res I 40: 1963-1972

Cotner JB, Ammerman JW, Peele ER, Bentzen E (1997) Phosphorus-limited bacterioplankton growth in the Sargasso Sea. Aquat Microb Ecol 13:141-149

del Giorgio P, Cole JJ (1998) Bacterial growth efficiency in natural aquatic systems. Annu Rev Ecol Syst 29:503-541

del Giorgio P, Cole JJ (2000) Bacterial energetics and growth efficiency. In: Kirchman DL (ed) Microbial ecology of the oceans. Wiley-Liss, New York, NY, p 289-325

DeLong EF, Preston CM, Mincer T, Rich V and others (2006) Community genomics among stratified microbial assemblages in the ocean's interior. Science 311:496-503

> Doval MD, Alvarez-Salgado XA, Perez FF (1997) Dissolved organic matter in a temperate embayment affected by coastal upwelling. Mar Ecol Prog Ser 157:21-37

> Ducklow HW, Purdie DA, Williams PJL, Davies JM (1986) Bacterioplankton: a sink for carbon in a coastal marine plankton community. Science 232:865-867

Ewart CS, Meyers MK, Wallner ER, McGillicuddy DJ, Carlson CA (2008) Microbial dynamics in cyclonic and anticyclonic mode-water eddies in the northwestern Sargasso Sea. Deep-Sea Res II 55:1334-1347

Farmer C, Hansell DA (2007) Determination of dissolved organic carbon and total dissolved nitrogen in seawater. In: Dickson AG, Sabine CL, Christian JR (eds) Guide to 
best practices for ocean $\mathrm{CO}_{2}$ measurements. PICES Special Publication 3:191

Fogg GE (1983) The ecological significance of extracellular products of phytoplankton photosynthesis. Bot Mar 26: $3-14$

Fram JP, Stewart HL, Brzezinski MA, Gaylord B, Reed DC, Williams SL, MacIntyre S (2008) Physical pathways and utilization of nitrate supply to the giant kelp, Macrocystis pyrifera. Limnol Oceanogr 53:1589-1603

Giovannoni SJ, Stingl U (2005) Molecular diversity and ecology of microbial plankton. Nature 437:343-348

> Goldberg SJ, Carlson CA, Hansell DA, Nelson NB, Siegel DA (2009) Temporal dynamics of dissolved combined neutral sugars and the quality of dissolved organic matter in the Northwestern Sargasso Sea. Deep-Sea Res I 56: 672-685

> Goldman JC, Hansell DA, Dennet MR (1992) Chemical characterization of three large oceanic diatoms: potential impact on water column chemistry. Mar Ecol Prog Ser 88: $257-270$

Goodman J, Brzezinski MA, Halewood ER, Carlson CA (2012) Sources of phytoplankton to the inner continental shelf in the Santa Barbara Channel inferred from crossshelf gradients in biological, physical and chemical parameters. Cont Shelf Res 48:27-39

> Hansell DA (2005) Dissolved organic carbon reference material program. EOS Trans Am Geophys Union 86: 318, doi:10.1029/2005EO350003

- Hansell DA, Carlson CA (1998) Net community production of dissolved organic carbon. Global Biogeochem Cycles 12:443-453

Hansell DA, Carlson CA (2001) Biogeochemistry of total organic carbon and nitrogen in the Sargasso Sea: control by convective overturn. Deep-Sea Res II 48:1649-1667

> Harms S, Winant CD (1998) Characteristic patterns of the circulation in the Santa Barbara Channel. J Geophys Res 103:3041-3065

> Hickey BM (1979) The California Current System-hypothesis and facts. Prog Oceanogr 8:191-279

> Hickey BM (1992) Circulation over the Santa Monica-San Pedro basin and shelf. Prog Oceanogr 30:37-115

> Hill JK, Wheeler PA (2002) Organic carbon and nitrogen in the northern California current system: comparison of offshore, river plume, and coastally upwelled waters. Prog Oceanogr 53:369-387

> Holligan PM, Harris RP, Newell RC, Harbour DS and others (1984) Vertical distribution and partitioning of organic carbon in mixed, frontal and stratified waters of the English Channel. Mar Ecol Prog Ser 14:111-127

Hoppe HG, Arnosti C, Herndl GJ (2002) Ecological significance of bacterial enzymes in the marine environment In: Burns RG, Dick RP (eds) Enzymes in the environment: activity, ecology, and applications. Marcel Dekker, New York, NY, p 73-108

- Karl DM, Hebel DV, Bjorkman K (1998) The role of dissolved organic matter release in the productivity of the oligotrophic North Pacific Ocean. Limnol Oceanogr 43: 1270-1286

> Lancelot C, Mathot S (1987) Dynamics of a Phaeocystisdominated spring bloom in Belgian coastal waters. I. Phytoplankton activities and related parameters. Mar Ecol Prog Ser 37:239-248

Lee S, Fuhrman JA (1987) Relationships between biovolume and biomass of naturally derived marine bacterioplankton. Appl Environ Microbiol 53:1298-1303
Lomas MW, Bates NR (2004) Potential controls on interannual partitioning of organic carbon during the winter/ spring phytoplankton bloom at the Bermuda Atlantic time-series study (BATS) site. Deep-Sea Res I 51: 1619-1636

Lønborg C, Søndergaard M (2009) Microbial availability and degradation of dissolved organic carbon and nitrogen in two coastal areas. Estuar Coast Shelf Sci 81: $513-520$

> Lønborg C, Martínez-García S, Teira E, Álvarez-Salgado XA (2011) Bacterial carbon demand and growth efficiency in a coastal upwelling system. Aquat Microb Ecol 63: 183-191

> Lucas AJ, Dupont CL, Tai V, Largier JL, Palenik B, Franks PJS (2011) The green ribbon: multiscale physical control of phytoplankton productivity and community structure over a narrow continental shelf. Limnol Oceanogr 56: 611-626

Lynn RJ, Simpson JJ (1987) The California Current system: the seasonal variability of its physical characteristics. J Geophys Res 92:12947-12966

- Mague TH, Friberg E, Hughes DJ, Morris I (1980) Extracellular release of carbon by marine phytoplankton; a physiological approach. Limnol Oceanogr 25:262-279

> Mann KH (1973) Seaweeds: their productivity and strategy for growth. Science 182:975-981

> Marie D, Partensky F, Jacquet S, Vaulot D (1997) Enumeration and cell cycle analysis of natural populations of marine picoplankton by flow cytometry using the nucleic acid stain SYBR Green I. Appl Environ Microbiol 63: 186-193

McPhee-Shaw E, Siegel DA, Washburn L, Brzezinski MA, Jones JL, Leydecker A, Melack J (2007) Mechanisms for nutrient delivery to the inner shelf: observations from the Santa Barbara Channel. Limnol Oceanogr 52:1748-1766

Nagata T (2000) Production mechanisms of dissolved organic matter. In: Kirchman DL (ed) Microbial ecology of the oceans. Wiley-Liss, New York, NY, p 121-152

Obernosterer I, Herndl GJ (1995) Phytoplankton extracellular release and bacterial growth; dependence on the inorganic N:P ratio. Mar Ecol Prog Ser 116:247-257

> Obernosterer I, Kawasaki N, Benner R (2003) P-limitation of respiration in the Sargasso Sea and uncoupling of bacteria from P-regeneration in size-fractionation experiments. Aquat Microb Ecol 32:229-237

> Ohlmann C, White P, Washburn L, Terrill E, Emery B, Otero M (2007) Interpretation of coastal HF radar-derived surface currents with high-resolution drifter data. J Atmos Ocean Technol 24:666-680

> Peltzer ET, Hayward NA (1996) Spatial and temporal variability of total carbon along $140^{\circ} \mathrm{W}$ in the equatorial Pacific Ocean in 1992. Deep-Sea Res II 43:1155-1180

> Pomeroy LR, Williams PJ, Azam F, Hobbie JE (2007) The microbial loop. Oceanography 20:28-33

> Rappé MS, Giovannoni SJ (2003) The uncultured microbial majority. Annu Rev Microbiol 57:369-394

> Reed D, Rassweiler A, Arkema K (2009) Density derived estimates of standing crop and net primary production in the giant kelp Macrocystis pyrifera. Mar Biol 156: 2077-2083

> Sambrotto RN, Savidge G, Robinson C, Boyd P and others (1993) Elevated consumption of carbon relative to nitrogen in the surface ocean. Nature 363:248-250

Schlitzer R (2009) Ocean Data View, Version 4.1.3. http:// odv.awi.de 
Sharp JH (1977) Extracellular production of organic matter by marine phytoplankton: Do healthy cells do it? Limnol Oceanogr 22:381-399

Simon M, Azam F (1989) Protein content and protein synthesis rates of planktonic marine bacteria. Mar Ecol Prog Ser 51:201-213

Sintes E, Stoderegger K, Parada V, Herndl GJ (2010) Seasonal dynamics of dissolved organic matter and microbial activity in the coastal North Sea. Aquat Microb Ecol 60:85-95

Smith DC, Azam F (1992) A simple, economical method for measuring bacterial protein synthesis rates in seawater using ${ }^{3} \mathrm{H}$-leucine. Mar Microb Food Webs 6:107-114

Smith WO, Barber RT, Huntsman S (1977) Primary production off the coast of northwest Africa: excretion of dissolved organic matter and its heterotrophic uptake. Deep-Sea Res 24:35-47

Smith WO, Carlson CA, Ducklow HW, Hansell DA (1998) Growth dynamics of Phaeocystis antarctica-dominated plankton assemblages from the Ross Sea. Mar Ecol Progr Ser 168:229-244

Søndergaard M, Middelboe M (1995) A cross-system analysis of labile dissolved organic carbon. Mar Ecol Prog Ser 118:283-294

Søndergaard M, Williams PJleB, Cauwet G, Riemann B and others (2000) Net accumulation and flux of dissolved

Editorial responsibility: Paul del Giorgio,

Montreal, Canada organic carbon and dissolved organic nitrogen in marine planktonic communities. Limnol Oceanogr 45:1097-1111

Teixeira de Mattos MJ, Neijssel OM (1997) Bioenergetic consequences of microbial adaptation to low-nutrient environments. J Biotechnol 59:117-126

Thingstad TF, Hagström ^, Rassoulzadegan F (1997) Accumulation of degradable DOC in surface waters: Is it caused by a malfunctioning microbial loop? Limnol Oceanogr 42:398-404

> Tranvik LJ, Bertilsson S (2001) Contrasting effects of solar UV radiation on dissolved organic sources for bacterial growth. Ecol Lett 4:458-463

Vaulot D, Courties C, Partensky F (1989) A simple method to preserve oceanic phytoplankton for flow cytometric analyses. Cytometry 10:629-635

Weiss MS, Abele U, Weckesser J, Welte W, Schiltz E, Schulz GE (1991) Molecular architecture and electrostatic properties of a bacterial porin. Science 254:1627-1630

Wetz MS, Wheeler PA (2003) Production and partitioning of organic matter during simulated phytoplankton blooms. Limnol Oceanogr 48:1808-1817

Williams PJLB (1995) Evidence for the seasonal accumulation of carbon-rich dissolved organic matter, its scale in comparison with changes in particulate material and consequential effect on net $\mathrm{C} / \mathrm{N}$ assimilation ratios. Mar Chem 51:17-29

Submitted: November 7, 2011; Accepted: July 18, 2012 Proofs received from author(s): October 16, 2012 